\title{
Building Assets Toolkit: Developing Positive Benchmarks for Adolescent Girls-Asset Cards [Swahili]
}

Judith Bruce

Population Council

Sarah Engebretsen

Population Council

Kimberly Glazer

Follow this and additional works at: https://knowledgecommons.popcouncil.org/departments_sbsr-pgy

Part of the Family, Life Course, and Society Commons, Health Communication Commons, International Public Health Commons, and the Women's Health Commons How does access to this work benefit you? Let us know!

\section{Recommended Citation}

Bruce, Judith, Sarah Engebretsen, and Kimberly Glazer. 2019. "Building Assets Toolkit: Developing Positive Benchmarks for Adolescent Girls-Asset Cards [in Swahili]." New York: Population Council. 
KADI ZA UJENZI WA RASLIMALI 


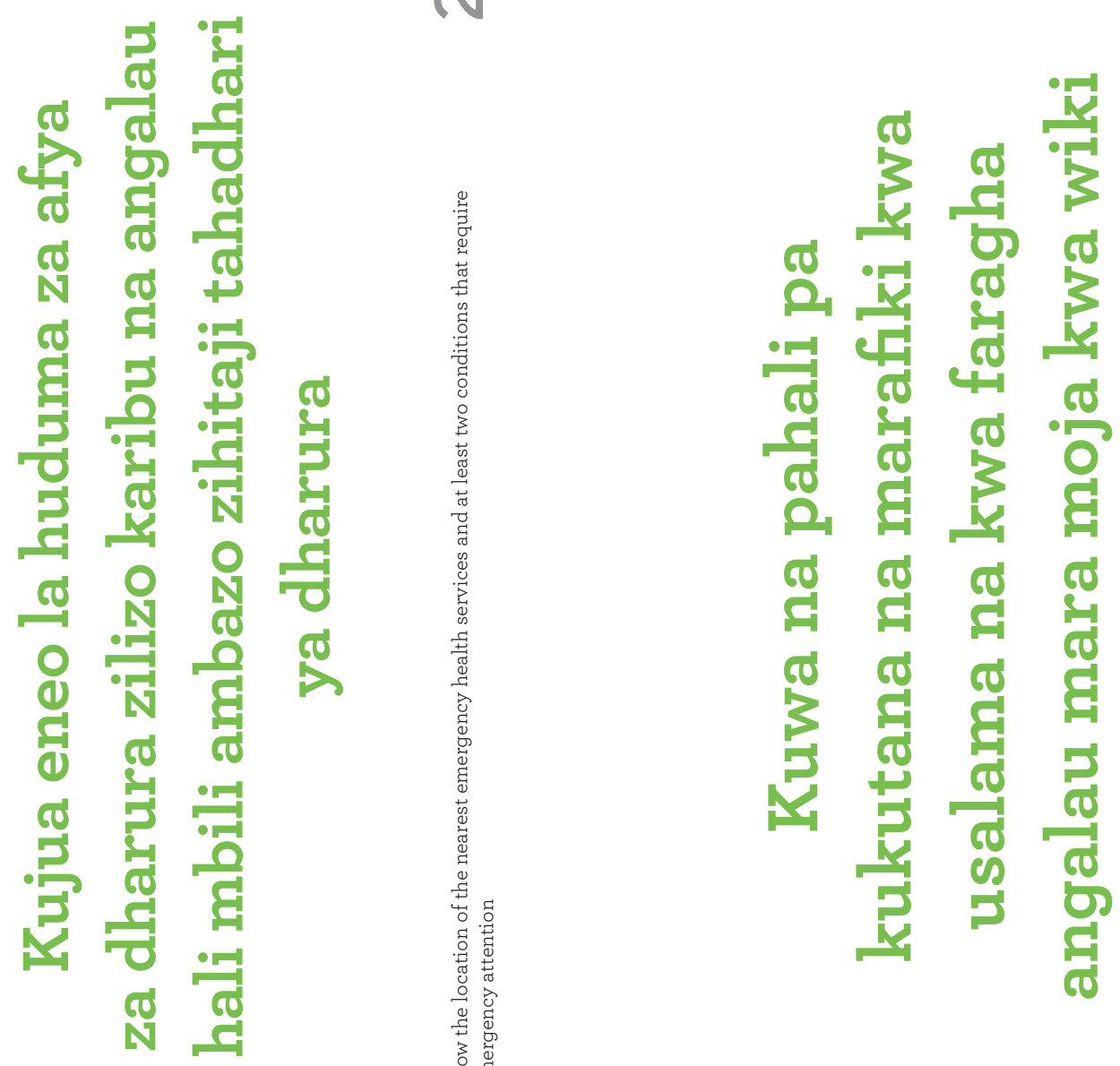

H
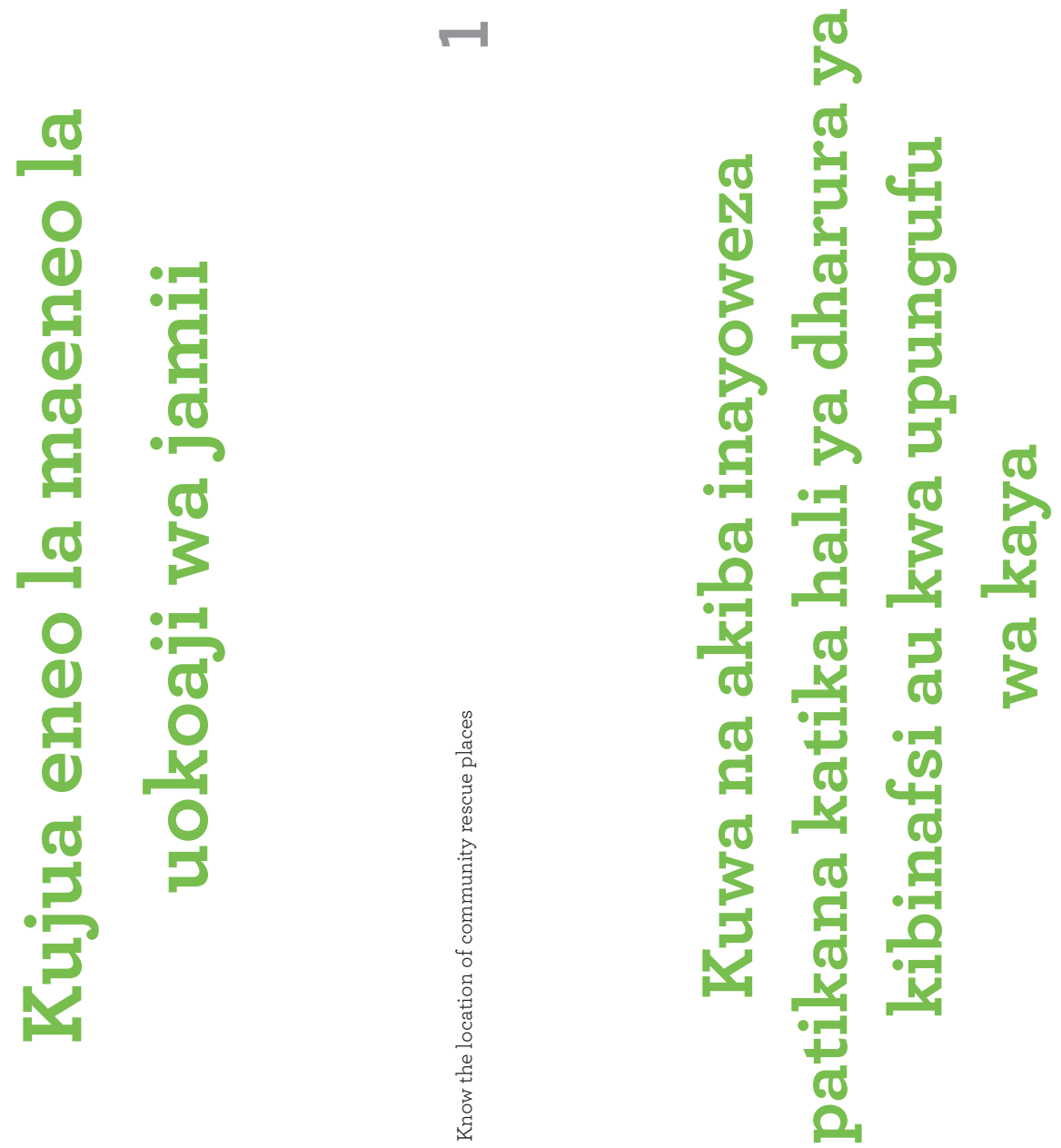

$m$ 


\section{0}

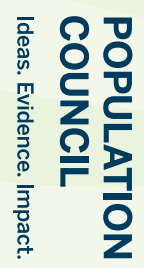

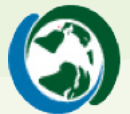

응응

(1)

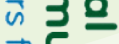

옥

คำ.

요
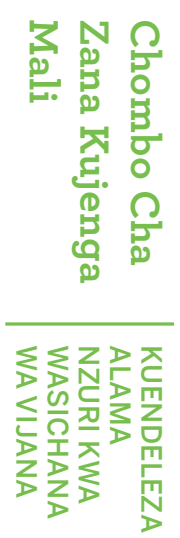

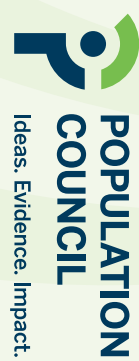

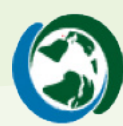

응응

으응

ज 3 을

옥

들.

ำ

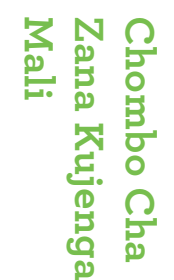

쪼고젇

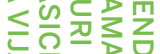

Z I

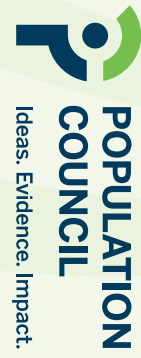

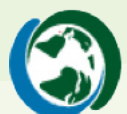

○ด

국응

ज 30

옥도

ด

ㅇํㅇ
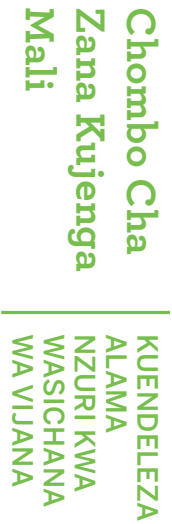
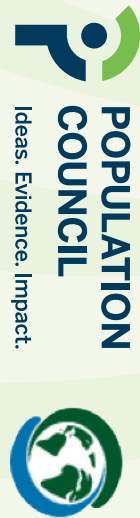

ำ

곡은

공

옥

ด

○ 

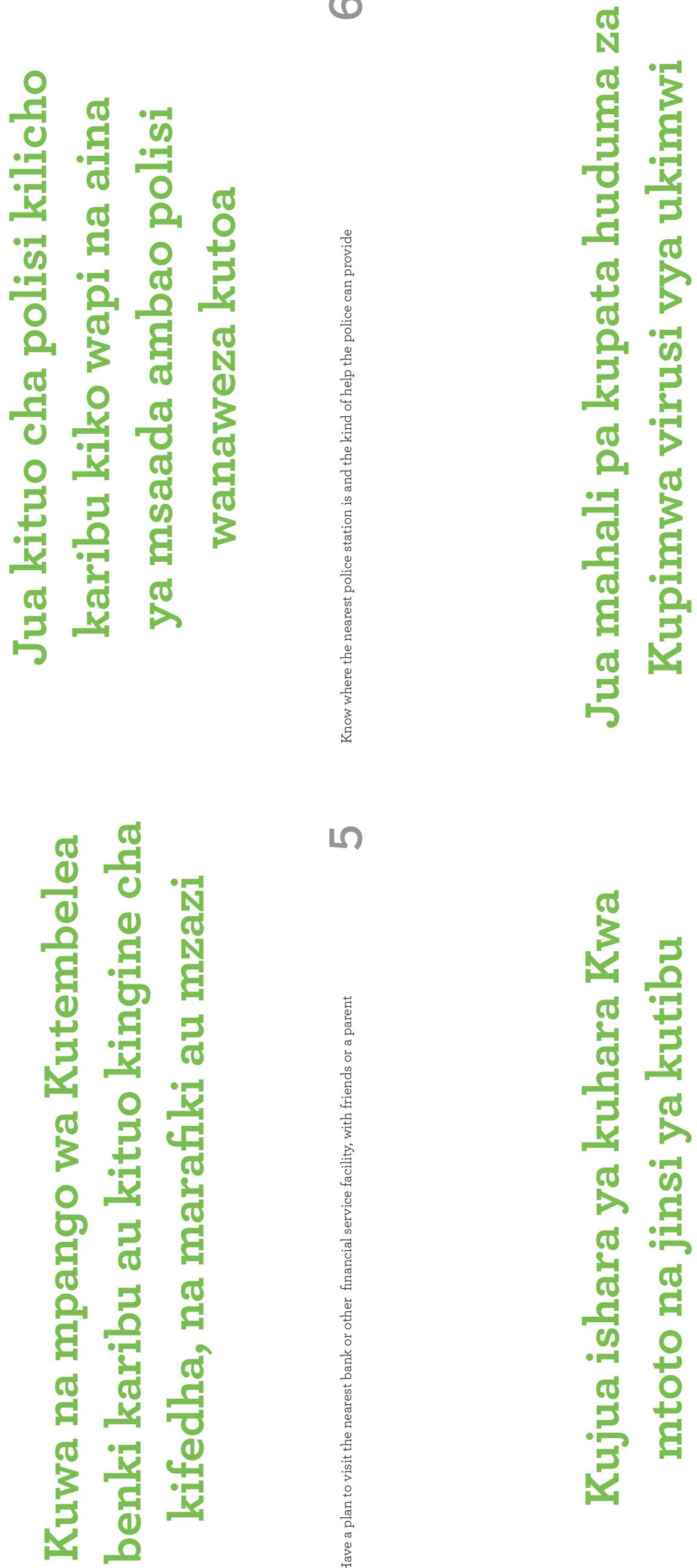


\section{0}

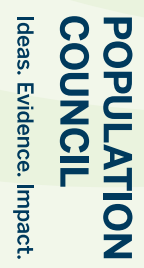

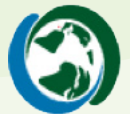

응응

(1)

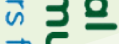

옥

คำ.

요
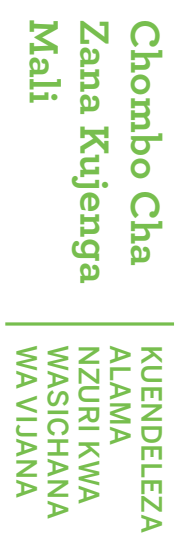

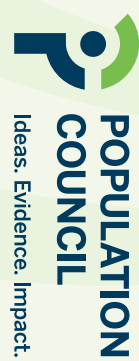

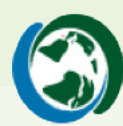

응응

으응

ज 3 을

옥

들.

ำ

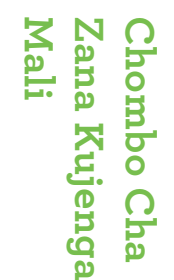

쪼고젇

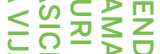

Z I

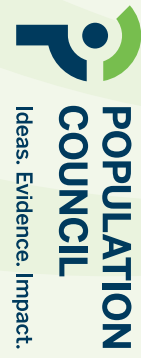

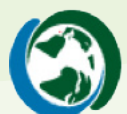

○ด

국응

ज 30

옥도

ด

ㅇํㅇ
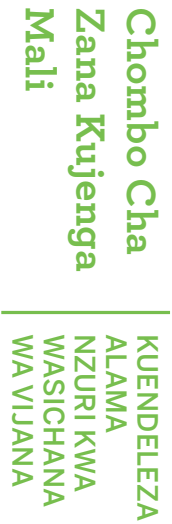
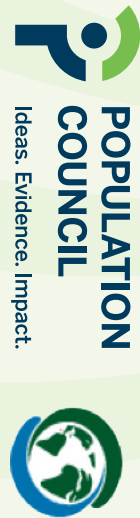

ำ

곡은

공

옥

ด

○ 

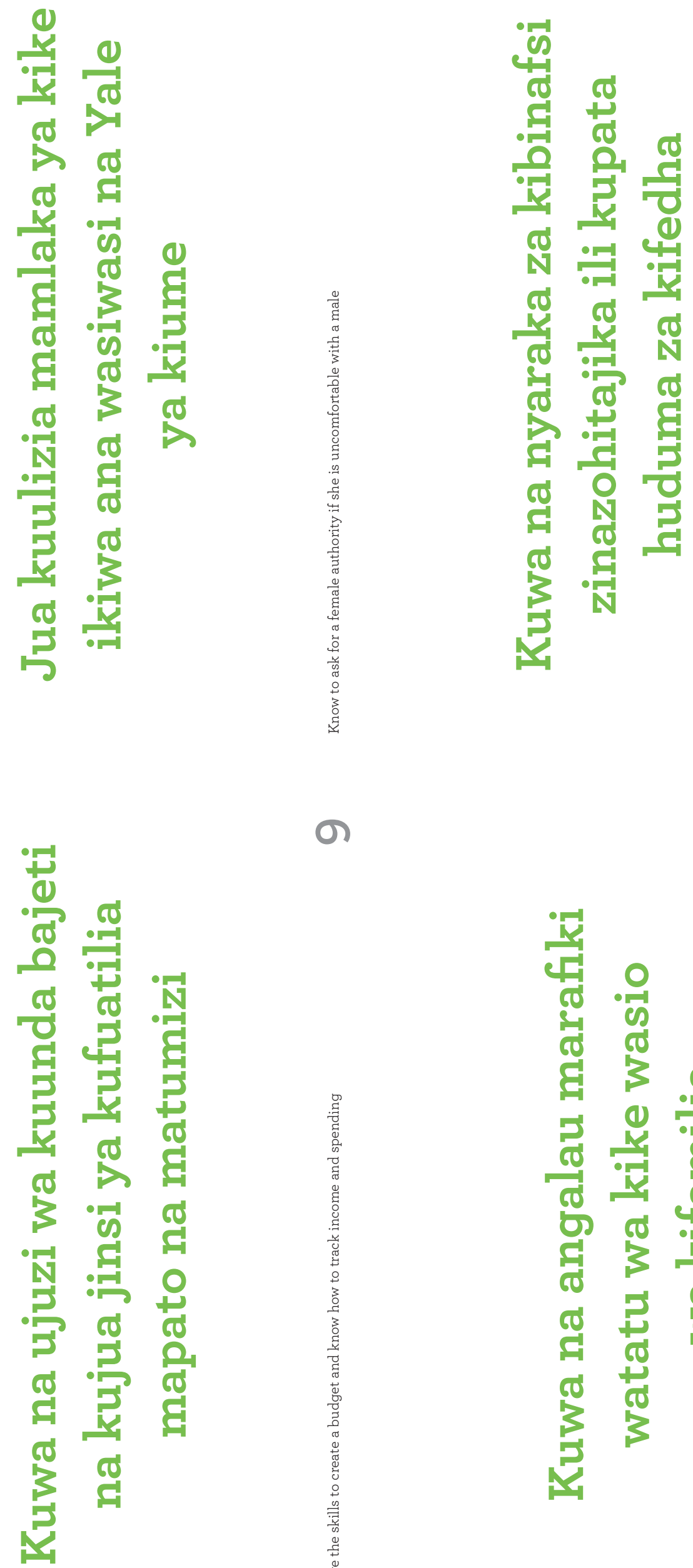

a
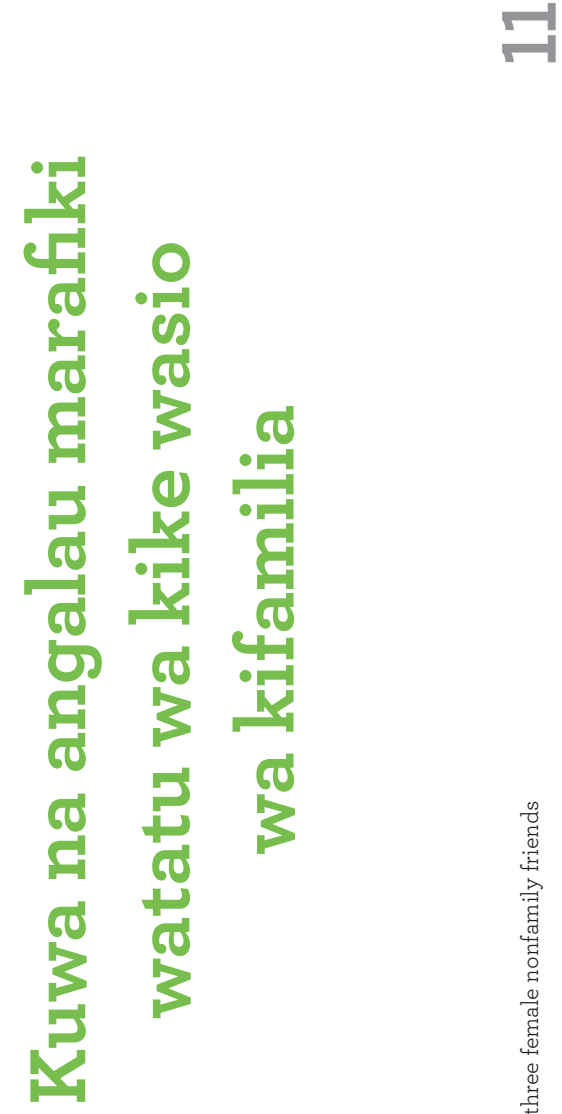


\section{0}

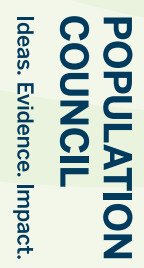

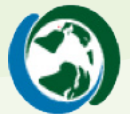

응응

(1)

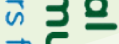

옥

คำ.

요
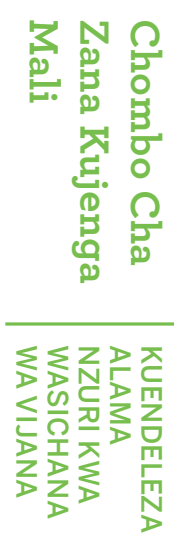

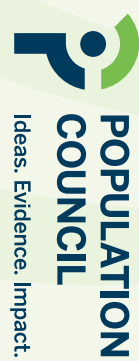

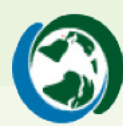

응응

으응

ज 3 을

옥

들.

ำ

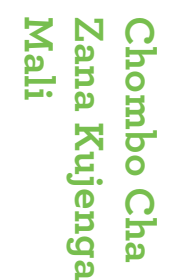

쪼고젇

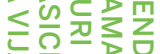

Z I

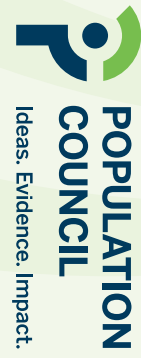

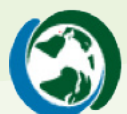

○ด

국응

ज 30

옥도

ด

ㅇํㅇ
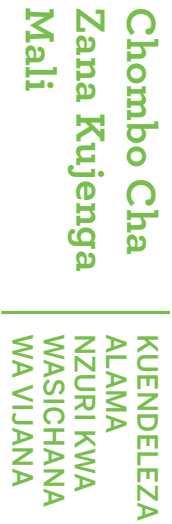
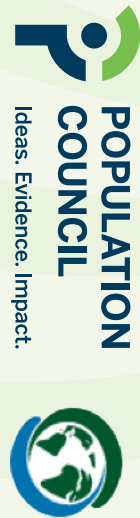

ำ

곡은

공

옥

ด

○ 

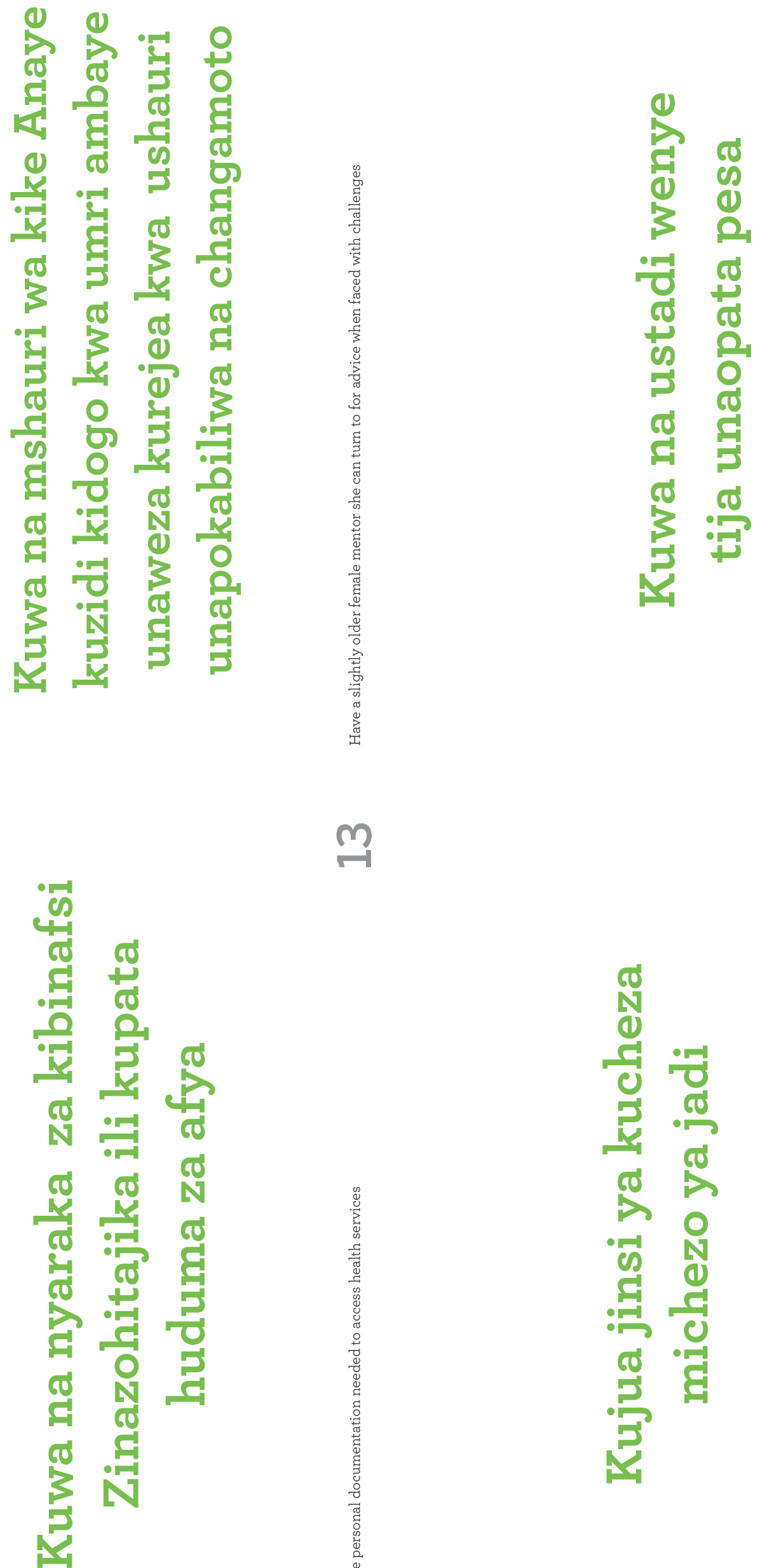

$m$

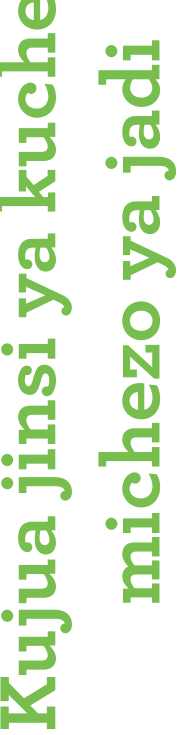




\section{0}

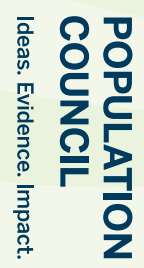

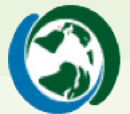

응응

(1)

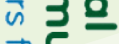

옥

คำ.

요
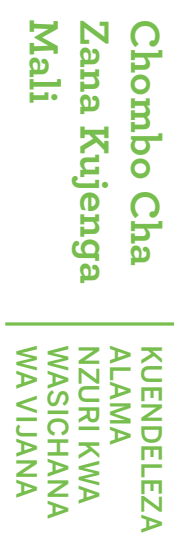

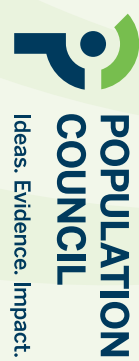

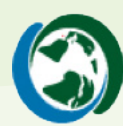

응응

으응

ज 3 을

옥

들.

ำ

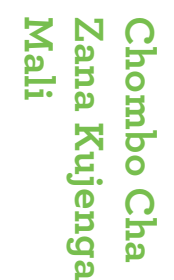

쪼고젇

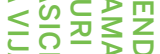

Z I

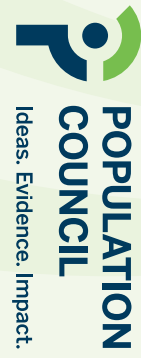

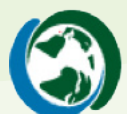

○ด

국응

ज 30

옥도

ด

ㅇํㅇ
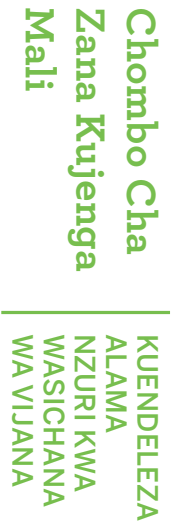
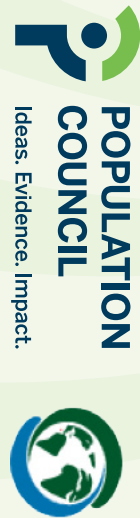

ำ

곡은

공

옥

ด

○ 

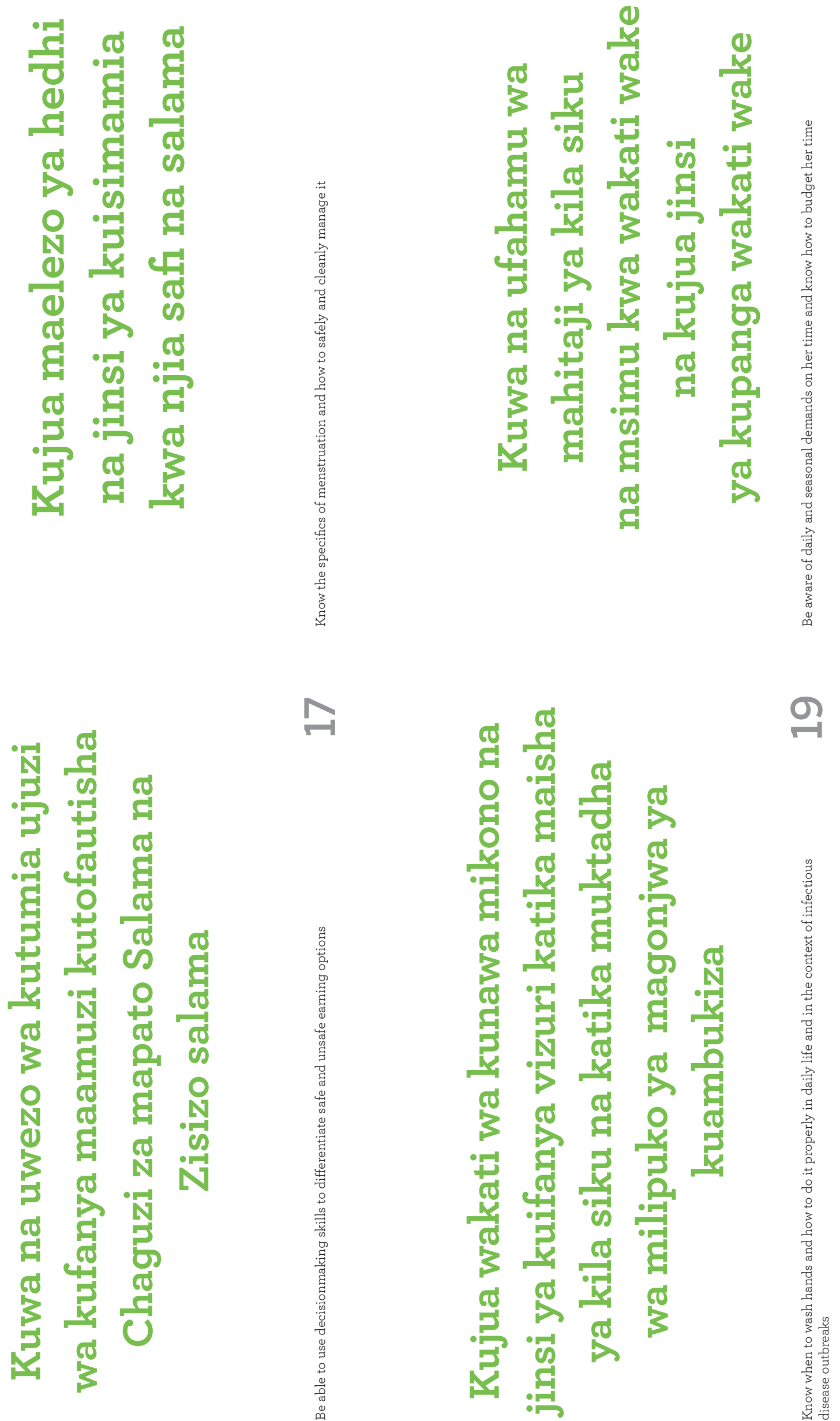


\section{0}

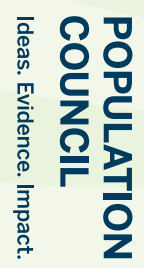

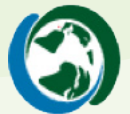

응응

(1)

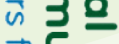

옥

คำ.

요
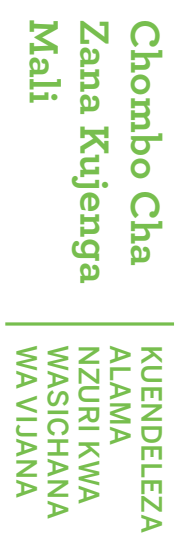

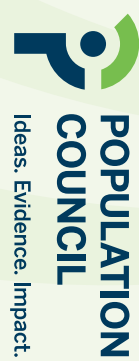

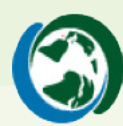

응응

으응

ज 3 을

옥

들.

ำ

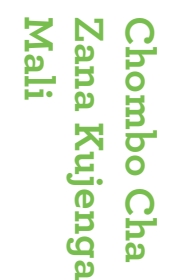

쪼고젇

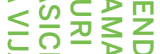

Z I

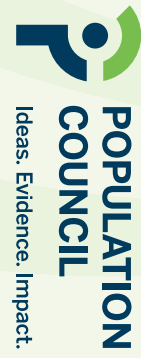

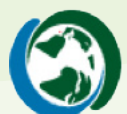

○ด

국응

ज 30

옥도

ด

ㅇํㅇ
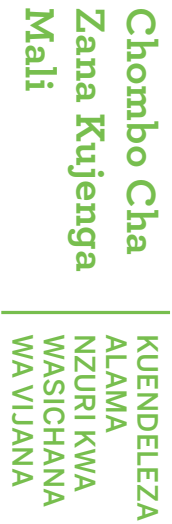
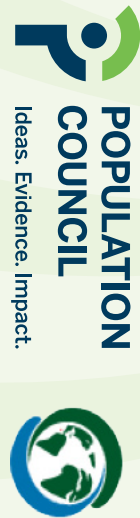

ำ

곡은

공

옥

ด

○ 


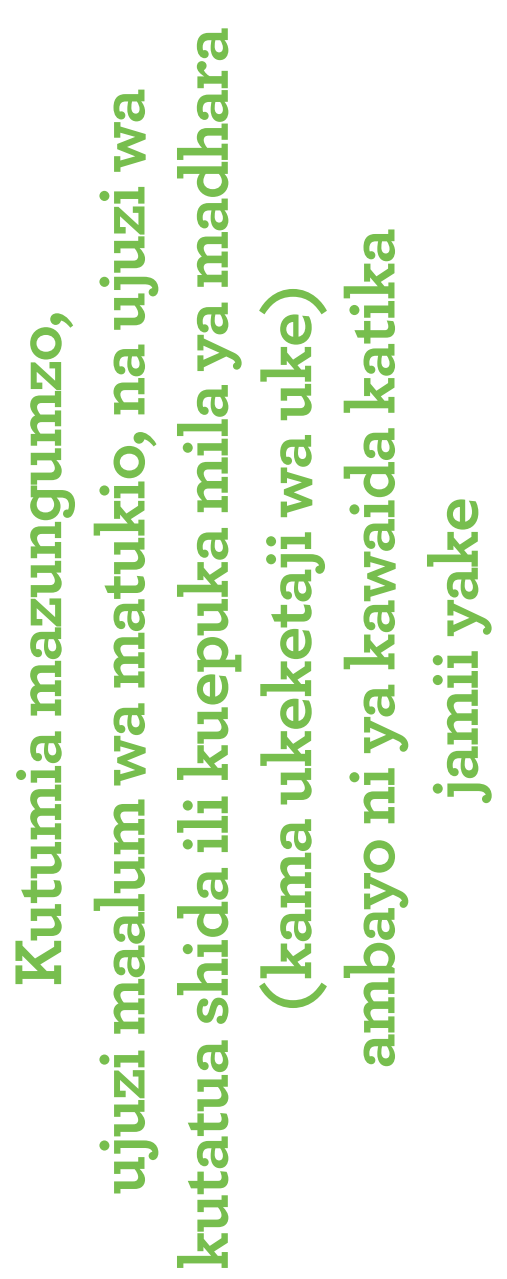

N
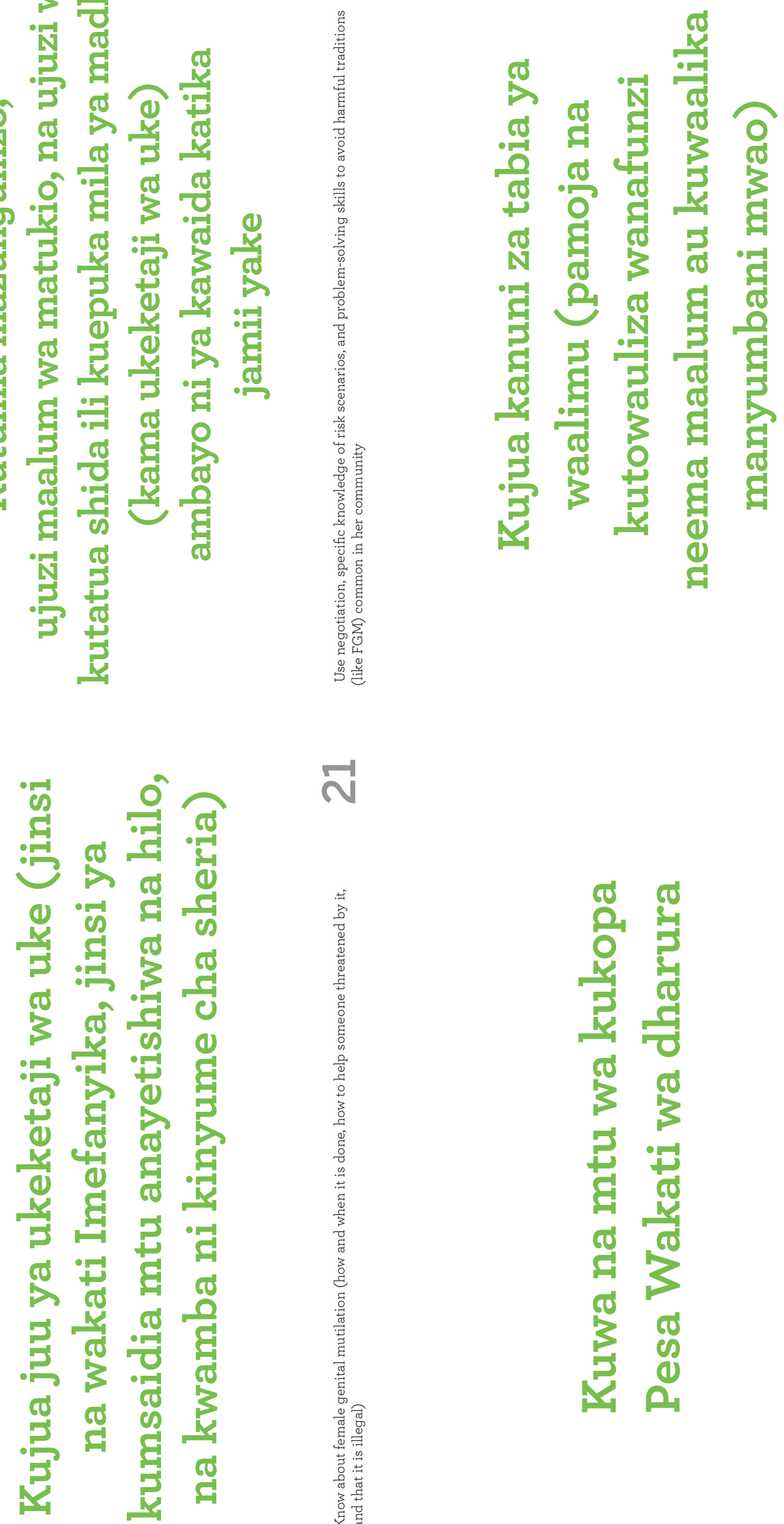

N

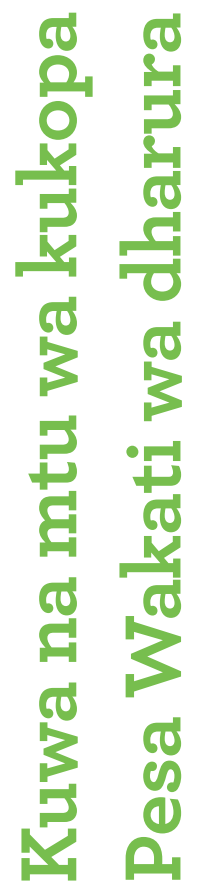




\section{0}

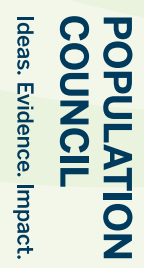

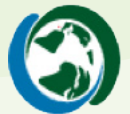

응응

(1)

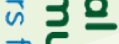

옥

คำ.

요
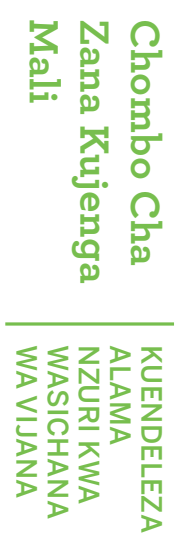

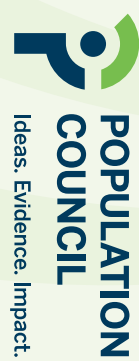

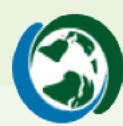

응응

으응

ज 3 을

옥

들.

ำ

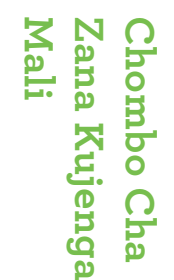

쪼고젇

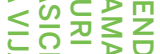

Z I

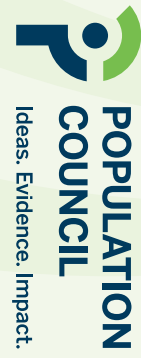

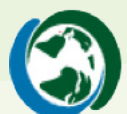

○ด

국응

ज 30

옥도

ด

ㅇํㅇ
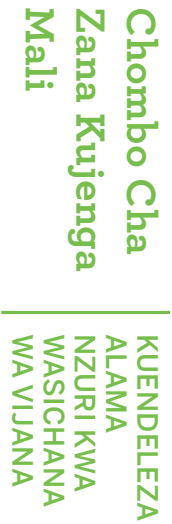
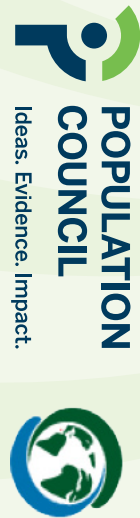

ำ

곡은

공

옥

ด

○ 

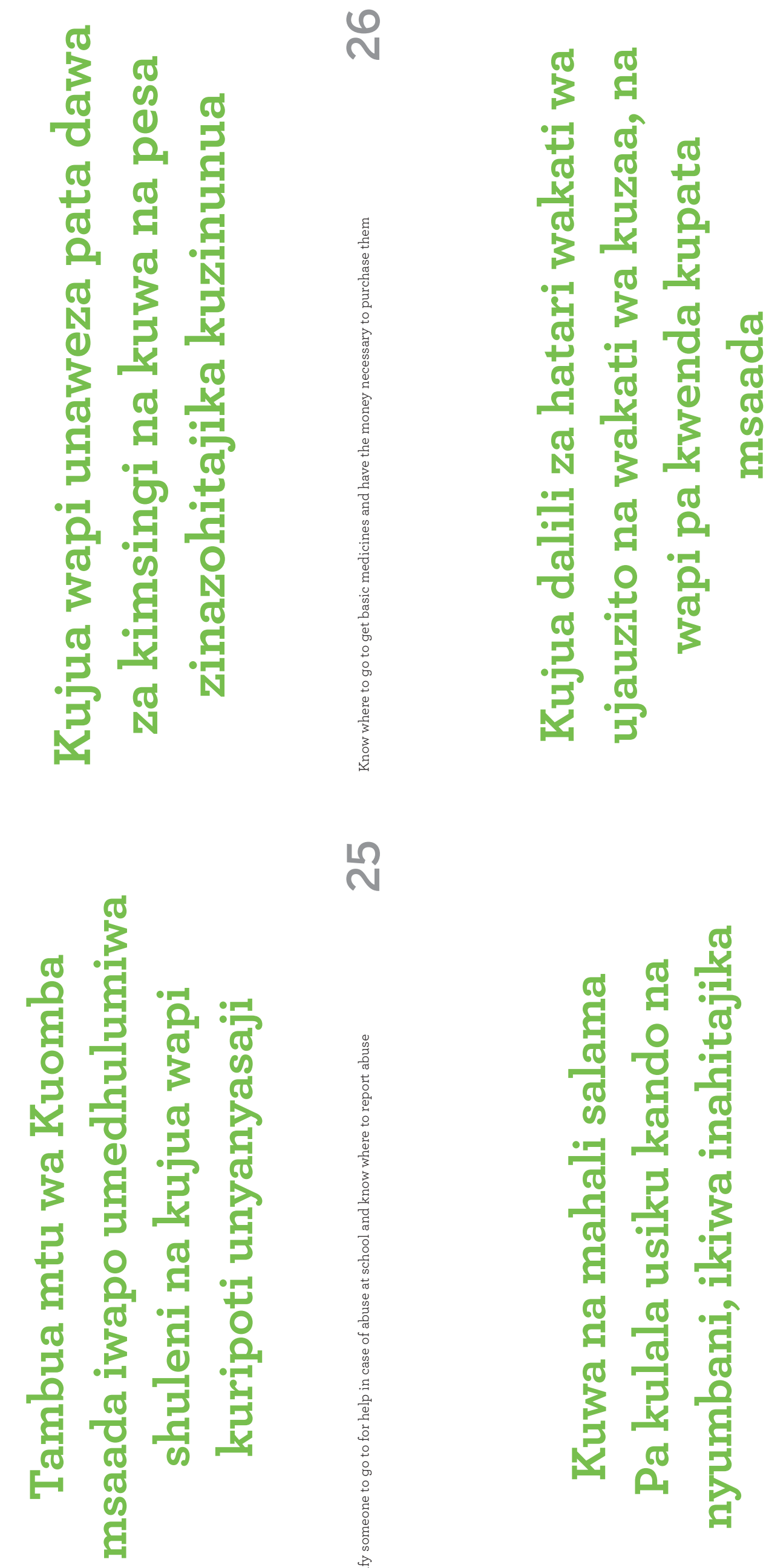

ก

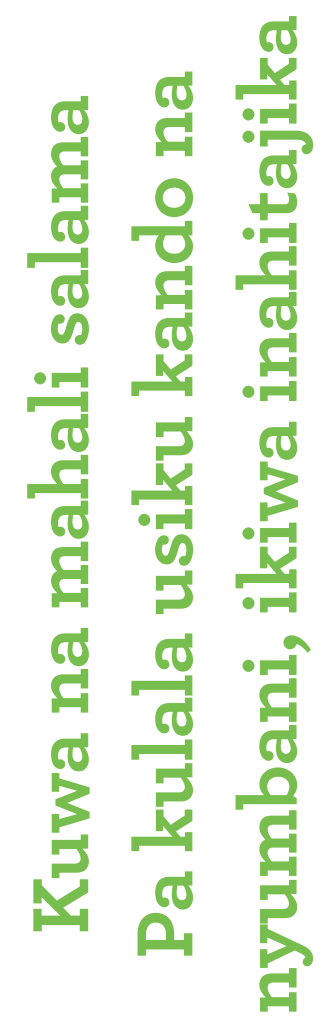




\section{0}

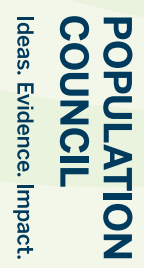

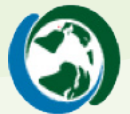

응응

(1)

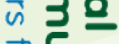

옥

คำ.

요
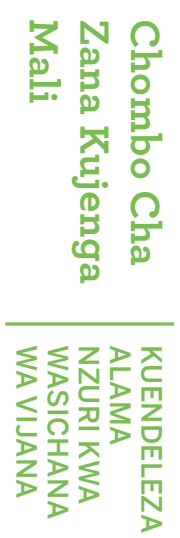

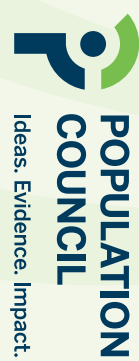

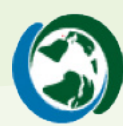

응응

으응

ज 3 을

옥

들.

ำ

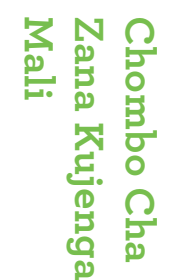

쪼고젇

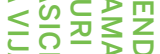

Z I

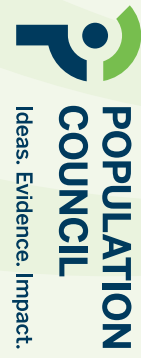

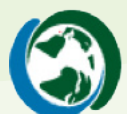

○ด

국응

ज 30

옥도

ด

ㅇํㅇ
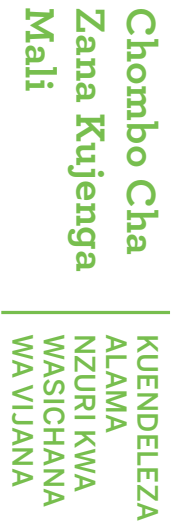
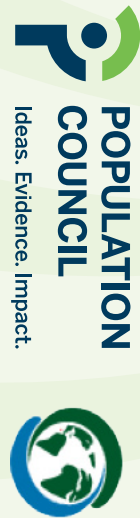

ำ

곡은

공

옥

ด

○ 

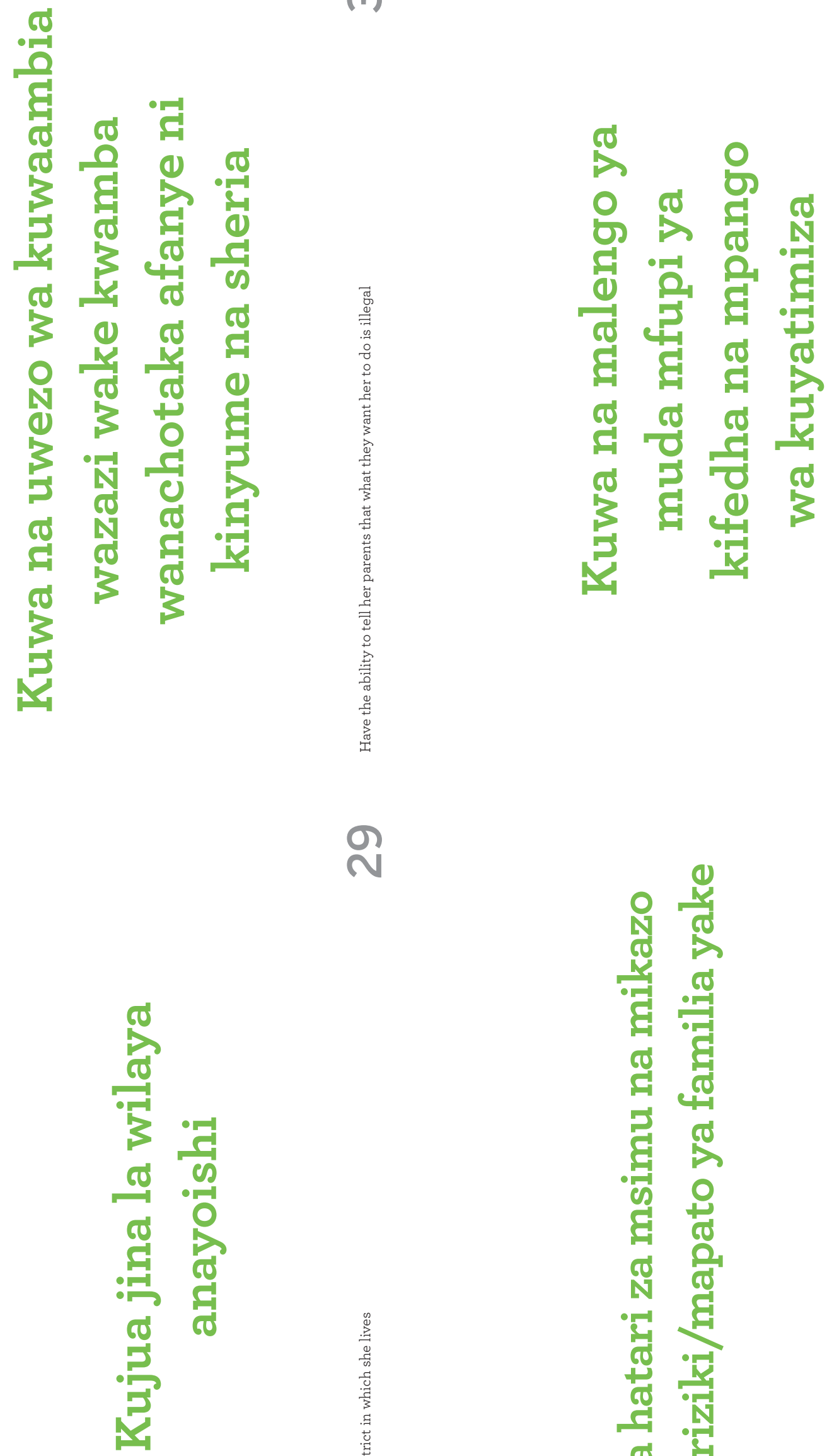

\%

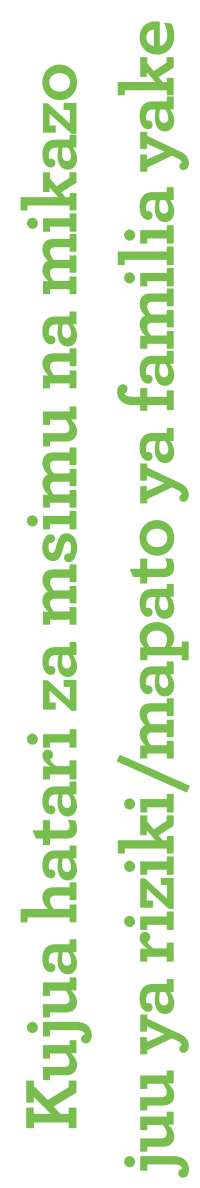

M 


\section{0}

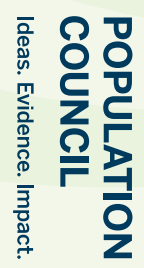

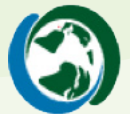

응응

(1)

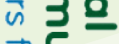

옥

คำ.

요
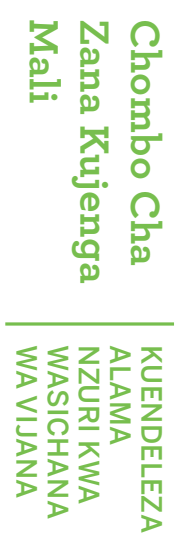

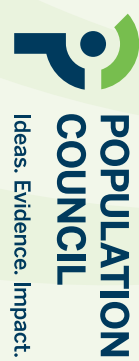

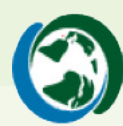

응응

으응

ज 3 을

옥

들.

ำ

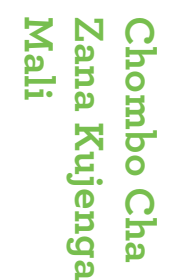

쪼고젇

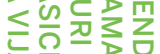

Z I

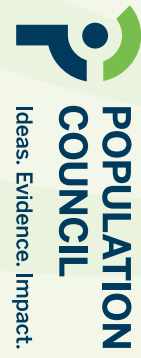

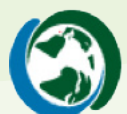

○ด

국응

ज 30

옥도

ด

ㅇํㅇ
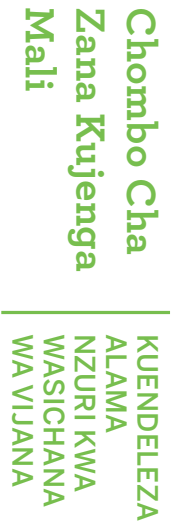
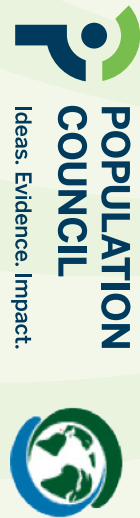

ำ

곡은

공

옥

ด

○ 

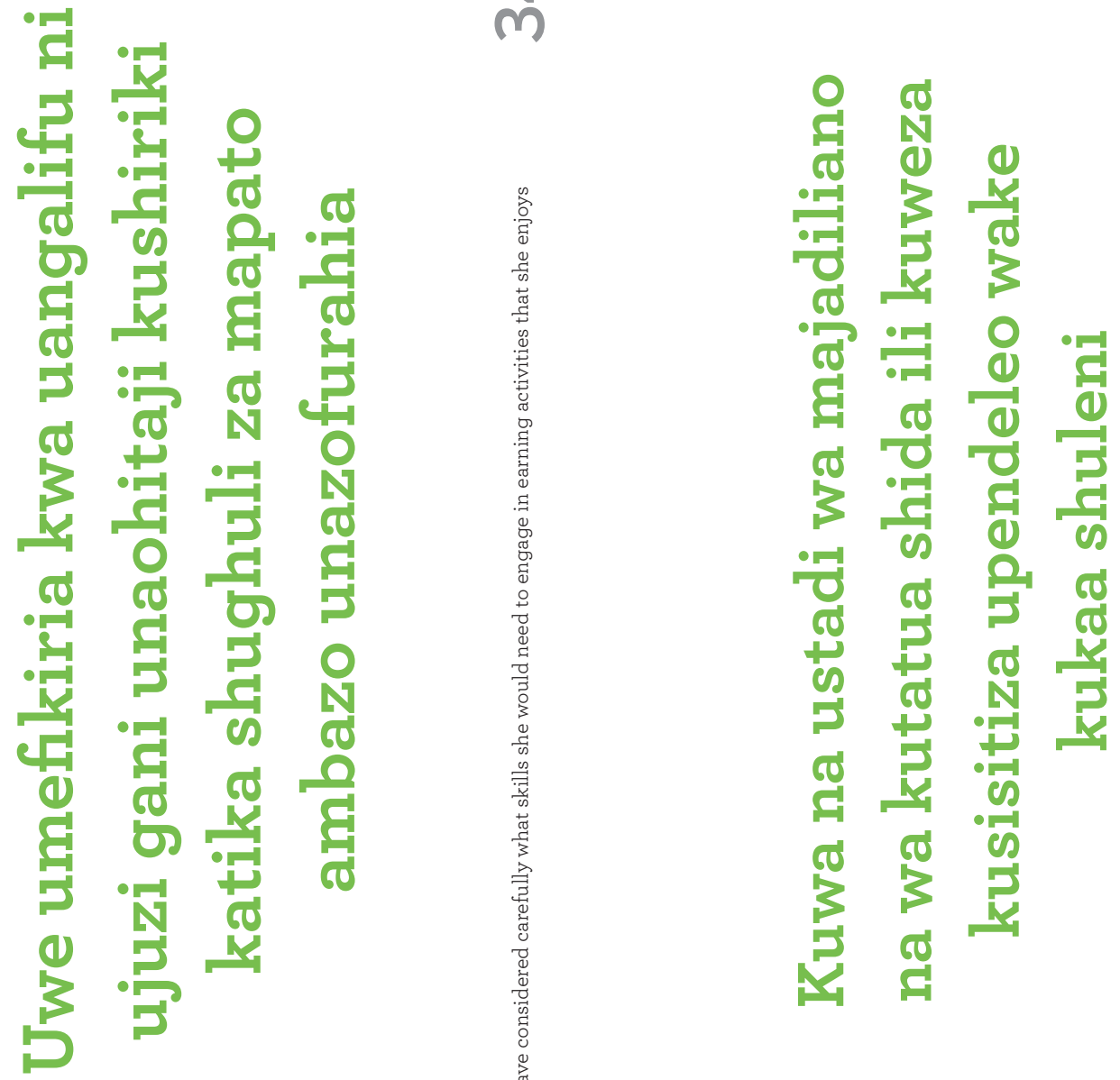

$m$
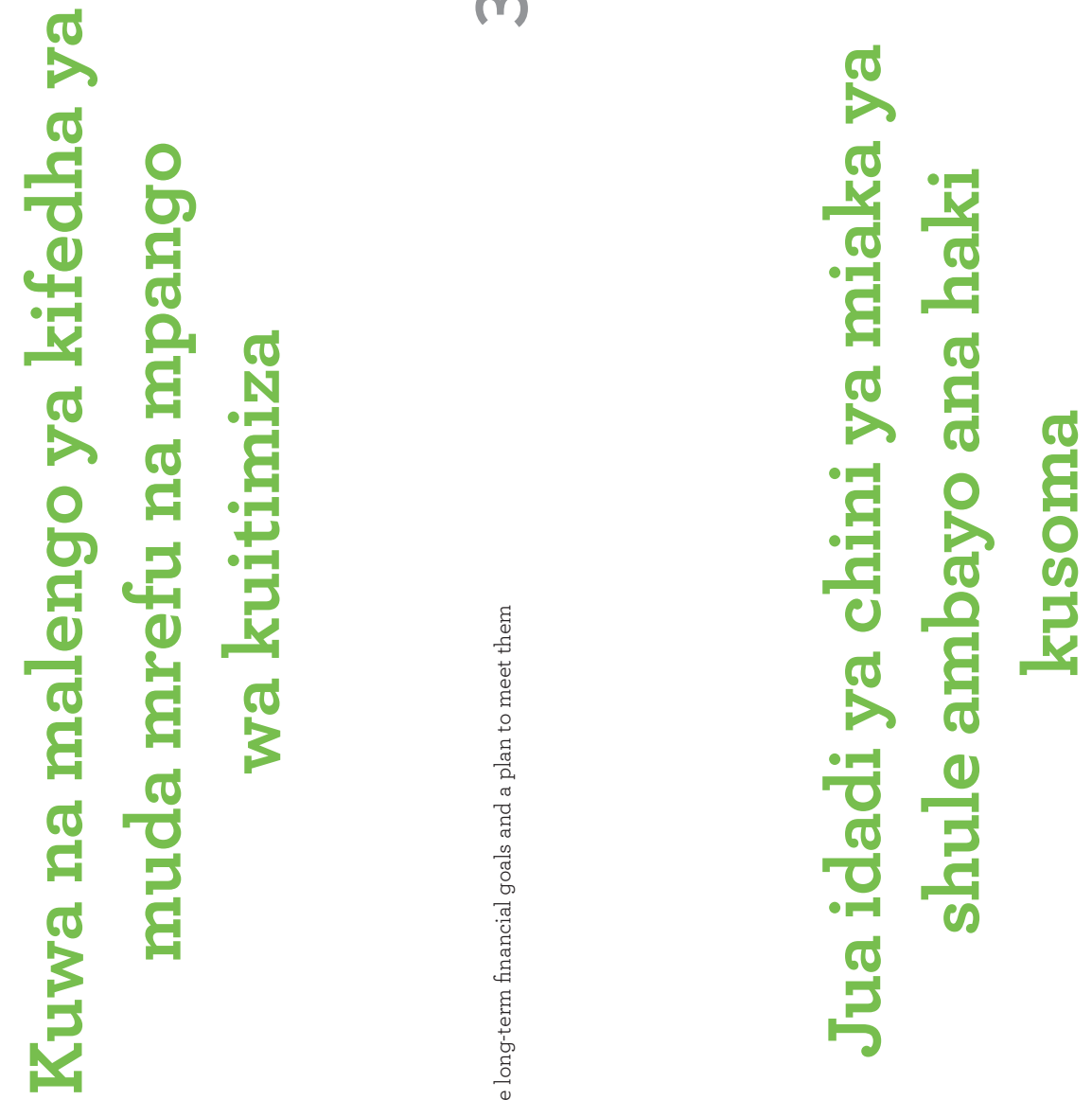


\section{0}

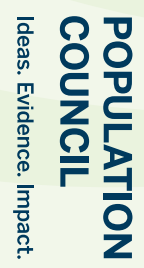

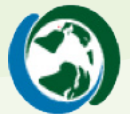

응응

(1)

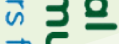

옥

คำ.

요
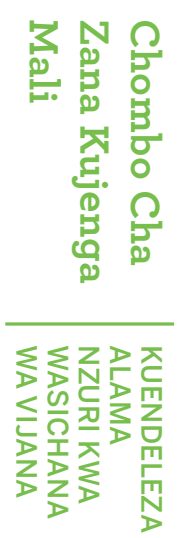

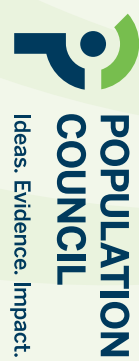

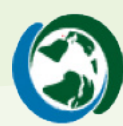

응응

으응

ज 3 을

옥

들.

ำ

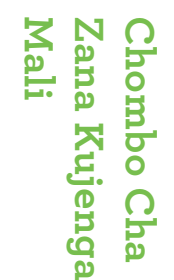

쪼고젇

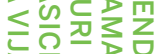

Z I

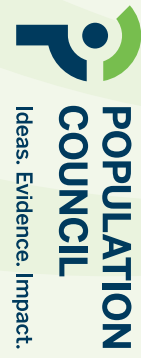

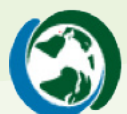

○ด

국응

ज 30

옥도

ด

ㅇํㅇ
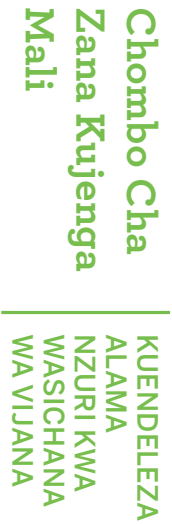
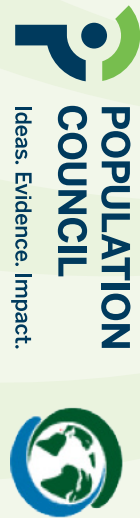

ำ

곡은

공

옥

ด

○ 

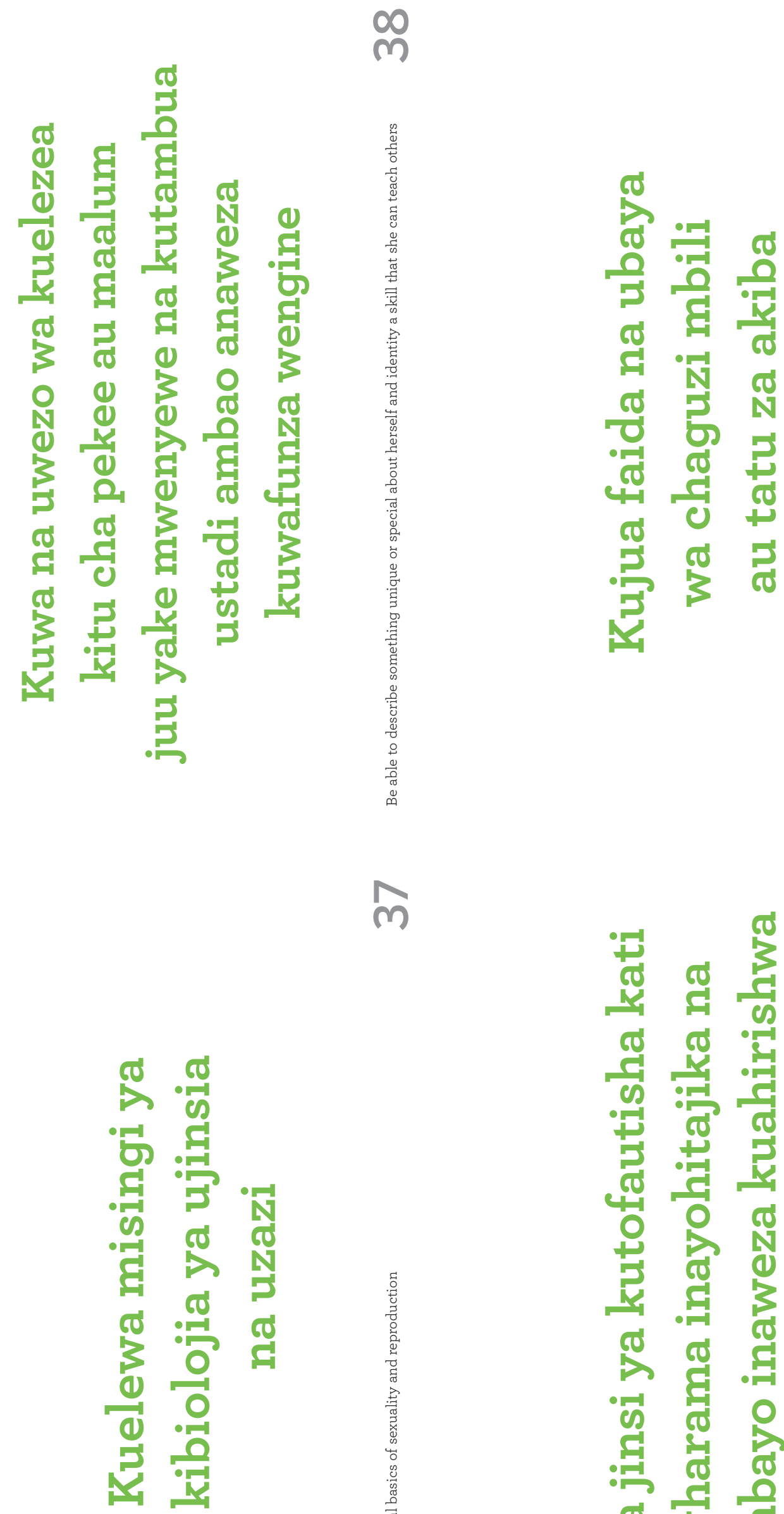

$m$

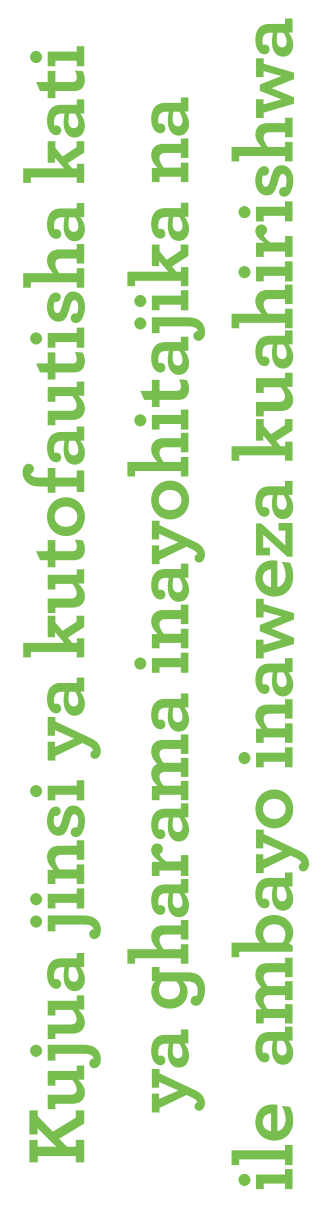




\section{0}

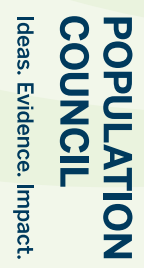

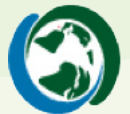

응응

(1)

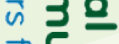

옥

คำ.

요
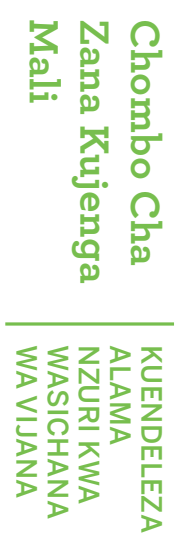

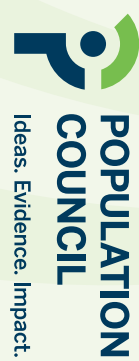

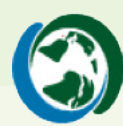

응응

으응

ज 3 을

옥

들.

ำ

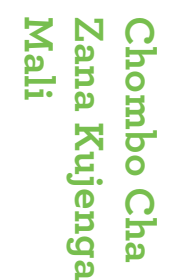

쪼고젇

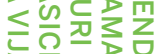

Z I

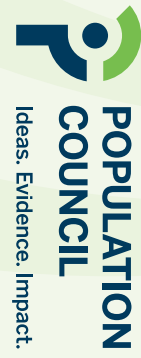

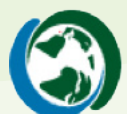

○ด

국응

ज 30

옥도

ด

ㅇํㅇ
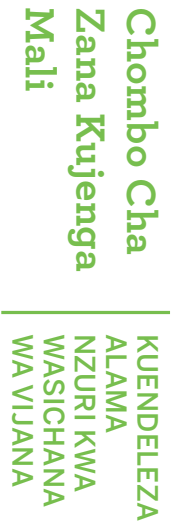
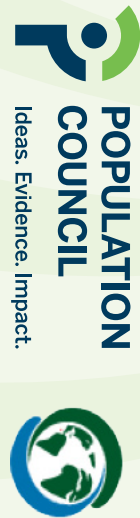

ำ

곡은

공

옥

ด

○ 

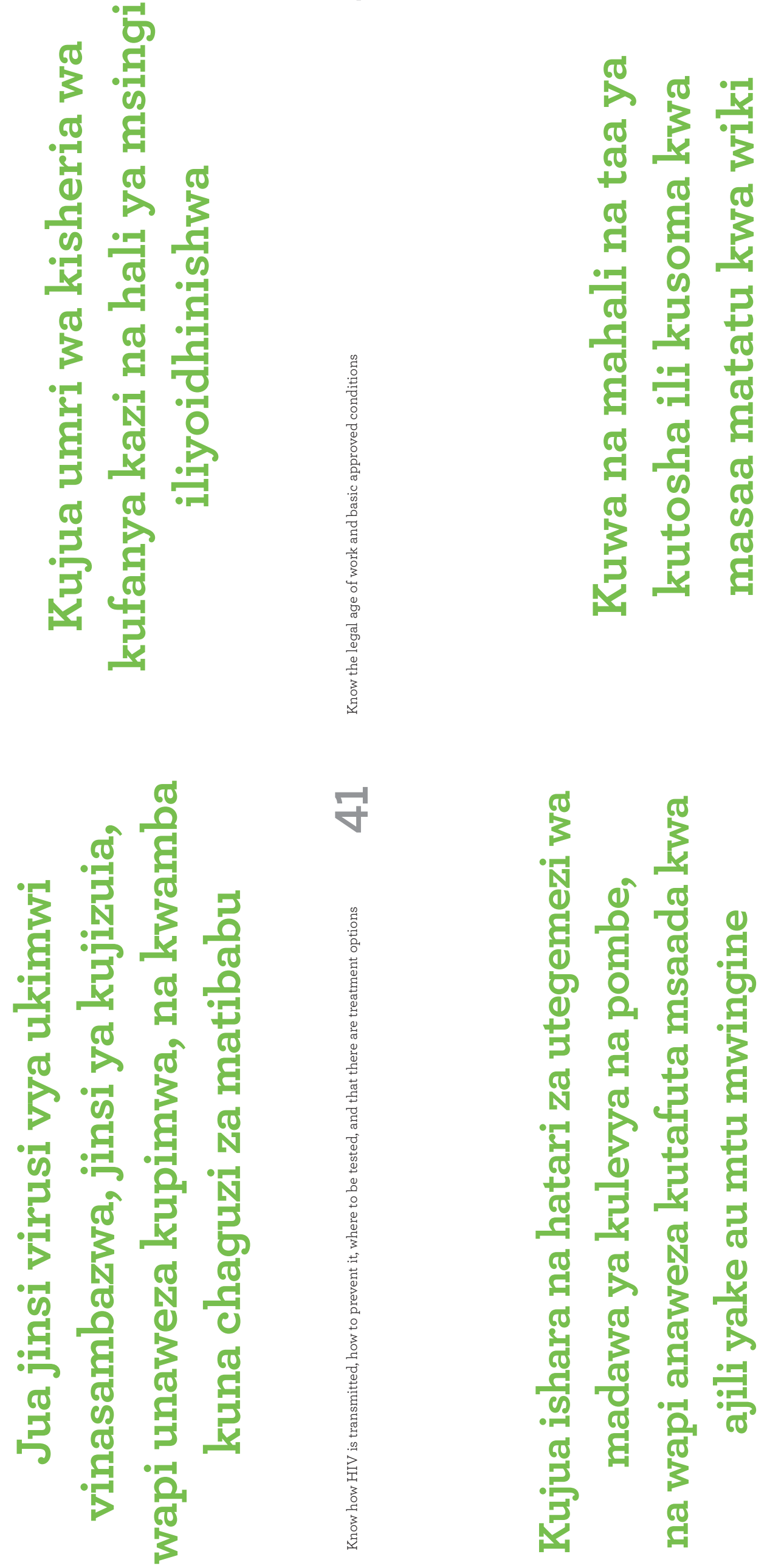

m 


\section{0}

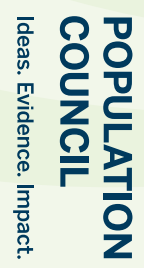

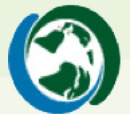

응응

(1)

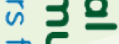

옥

คำ.

요
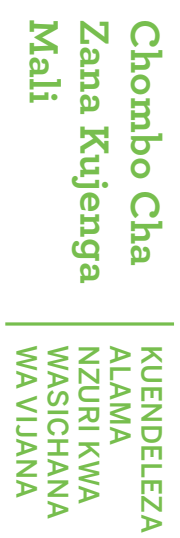

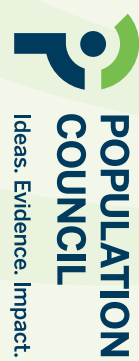

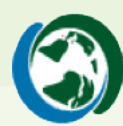

응응

으응

ज 3 을

옥

들.

ำ

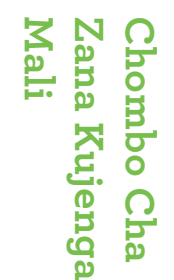

쪼고젇

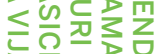

Z I

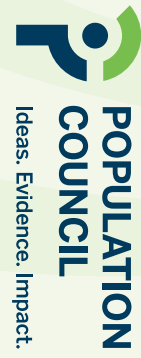

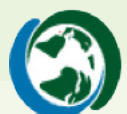

○ด

국응

ज 30

옥도

ด

ㅇํㅇ
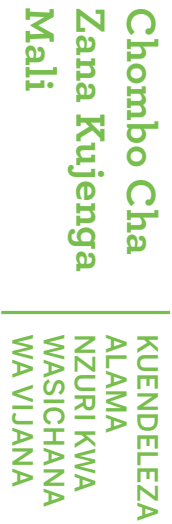
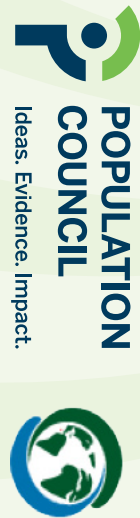

ำ

곡은

공

옥

ด

○ 


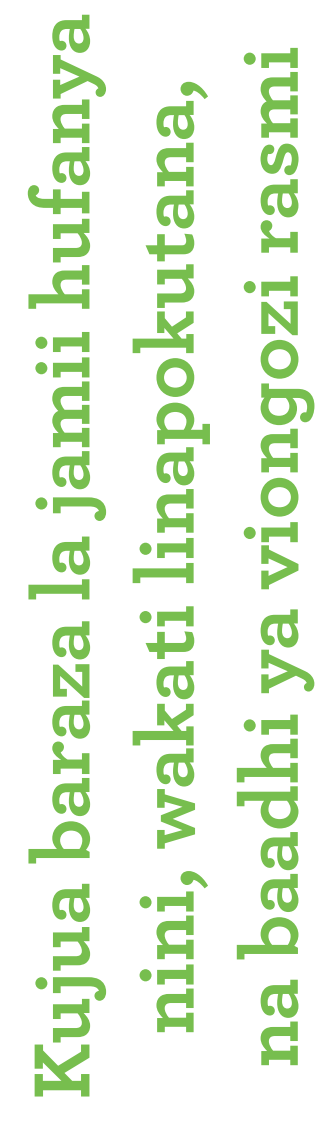

담
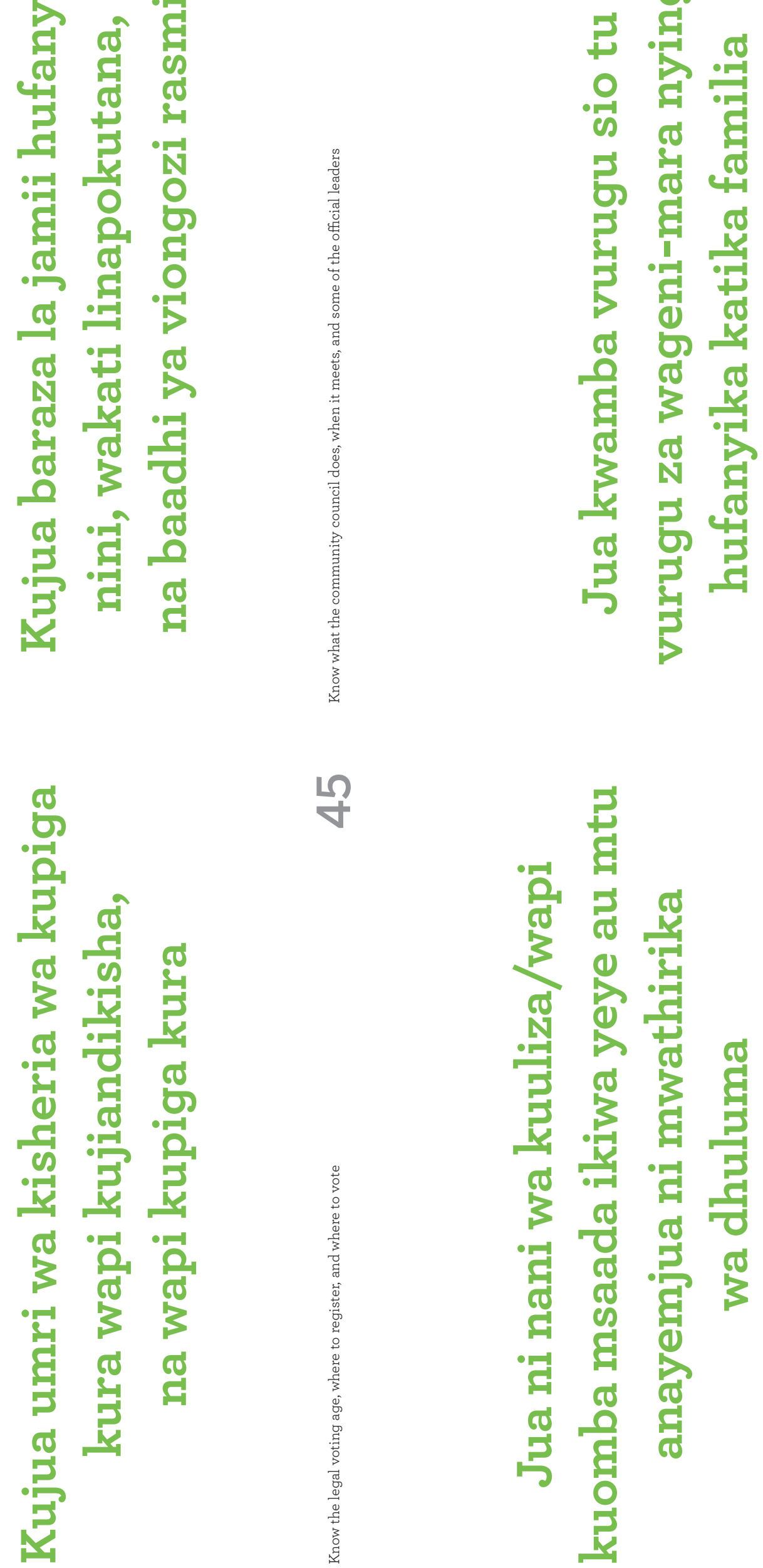

I

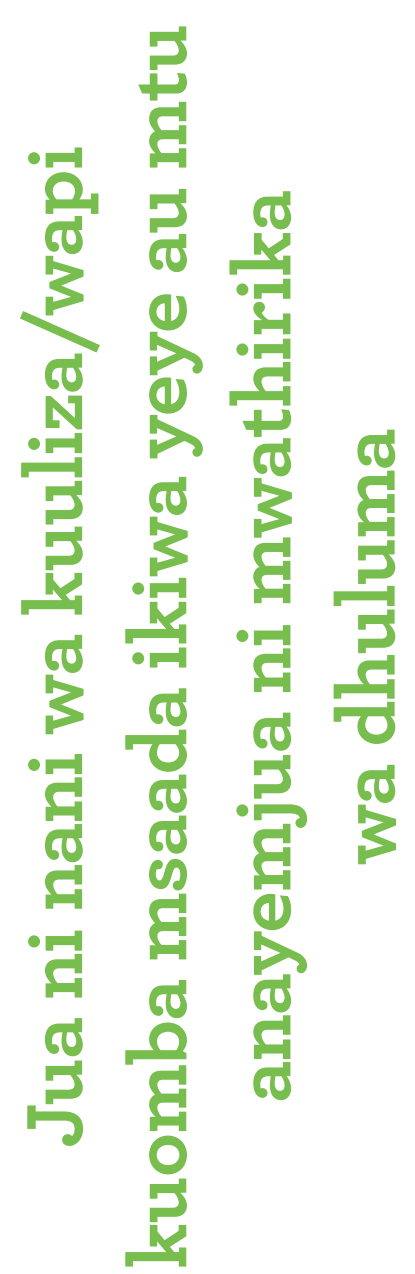




\section{0}

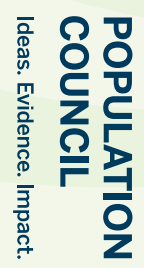

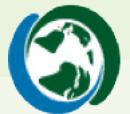

응응

(1)

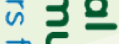

옥

คำ.

요
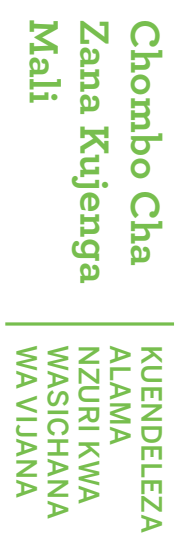

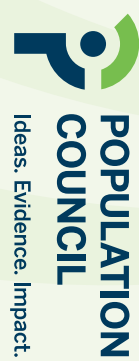

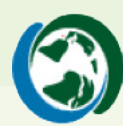

응응

으응

ज 3 을

옥

들.

ำ

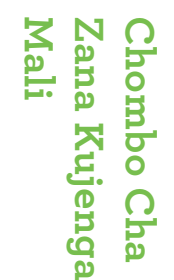

쪼고젇

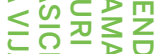

Z I

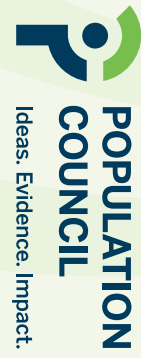

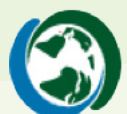

○ด

국응

ज 30

옥도

ด

ㅇํㅇ
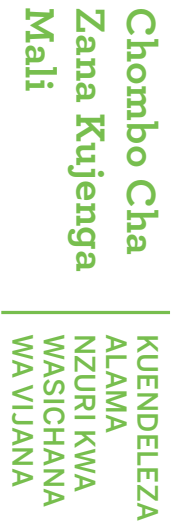
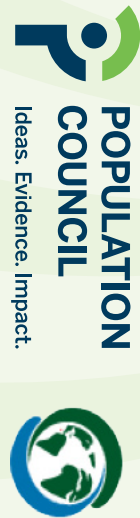

ำ

곡은

공

옥

ด

○ 

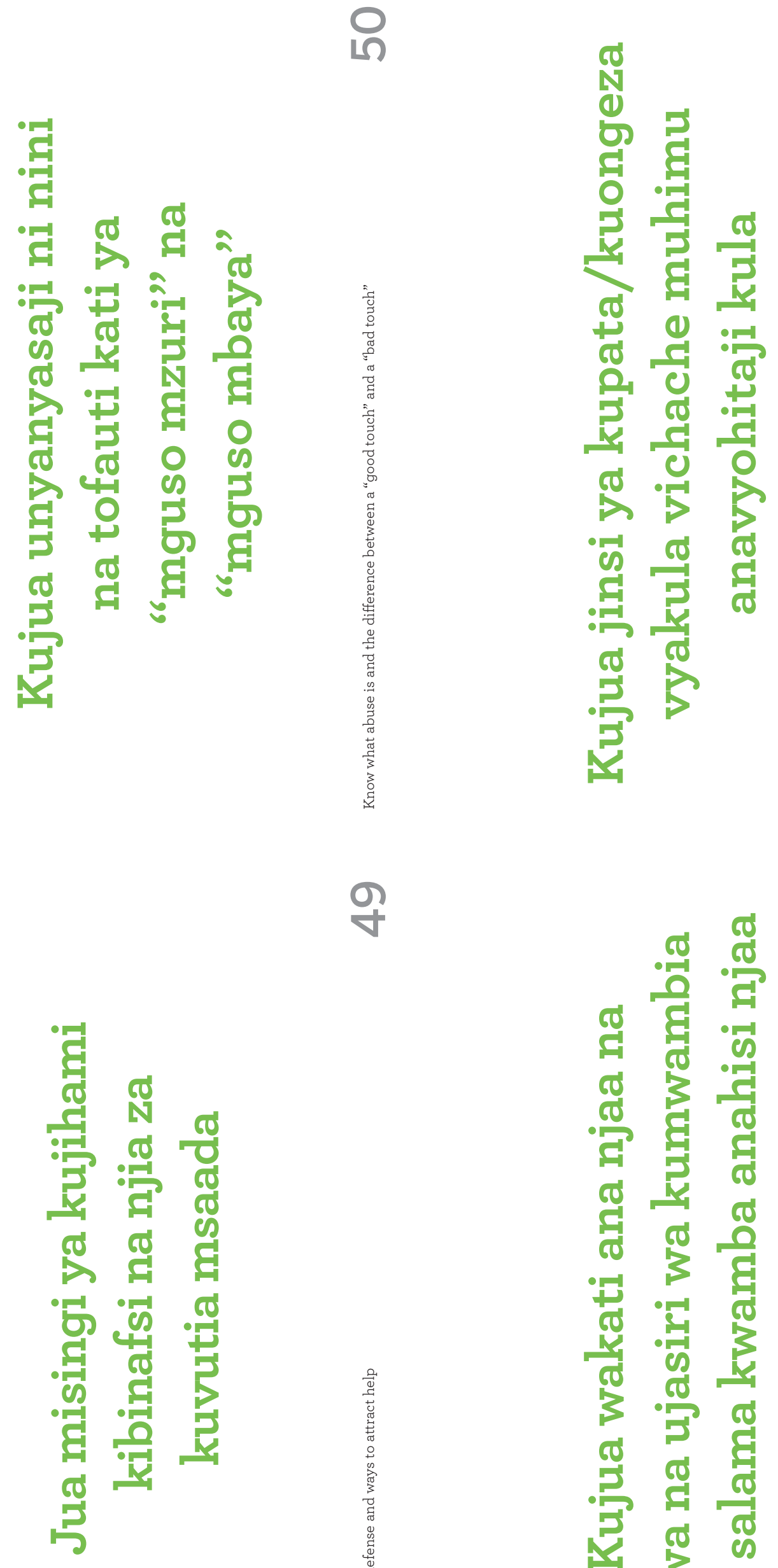

O

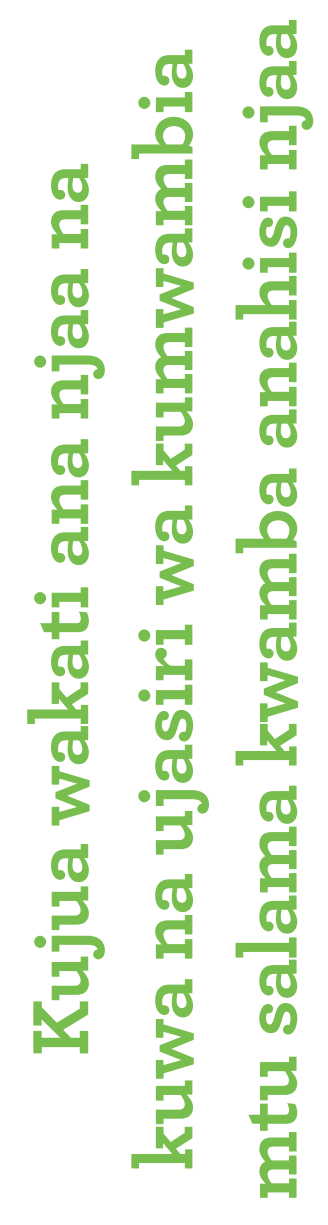




\section{0}

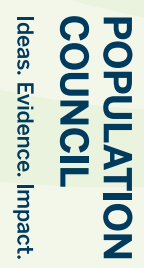

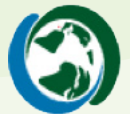

응응

(1)

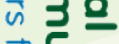

옥

คำ.

요
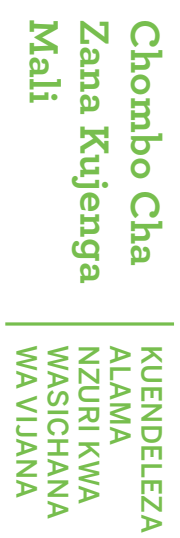

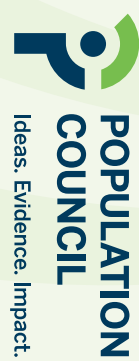

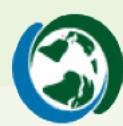

응응

으응

ज 3 을

옥

들.

ำ

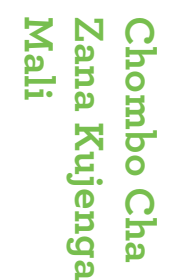

쪼고젇

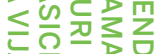

Z I

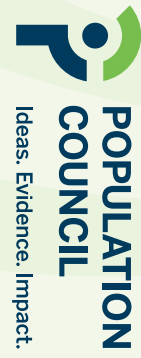

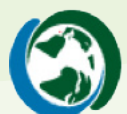

○ด

국응

ज 30

옥도

ด

ㅇํㅇ
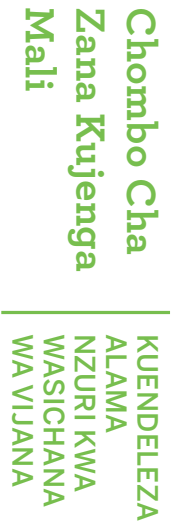
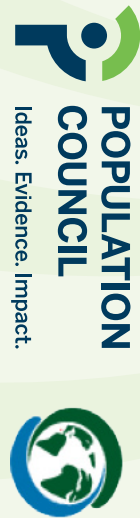

ำ

곡은

공

옥

ด

○ 

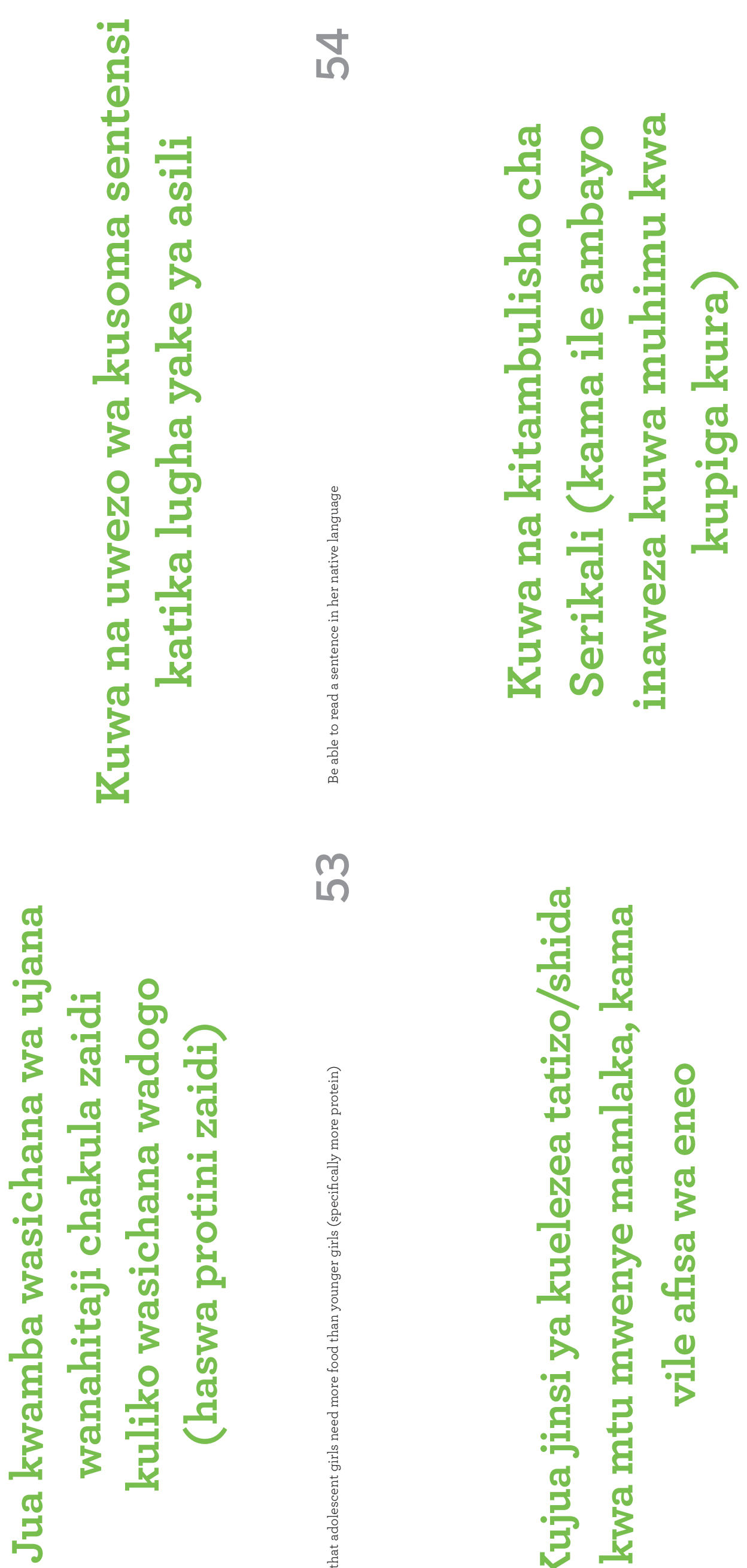

m

ก

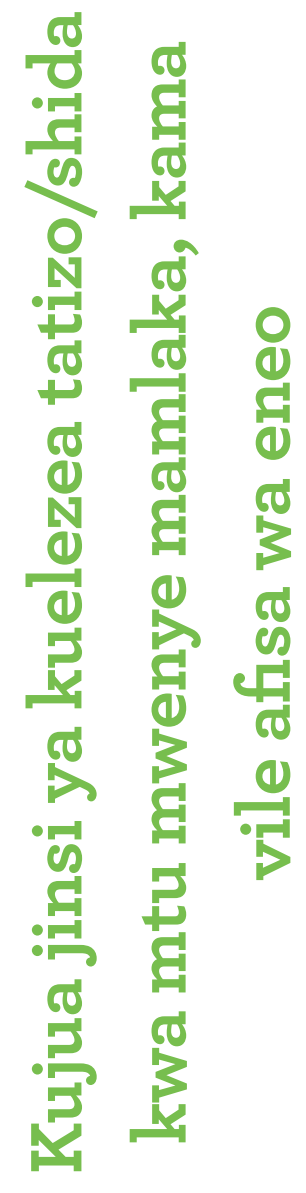




\section{0}

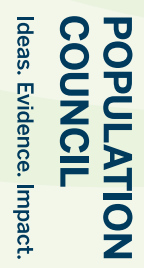

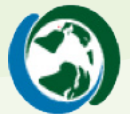

응응

(1)

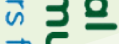

옥

คำ.

요
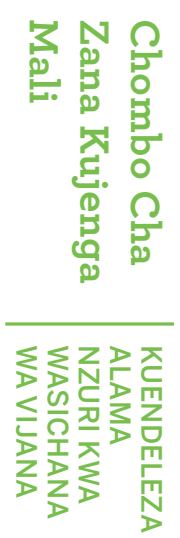

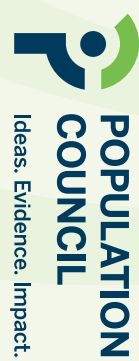

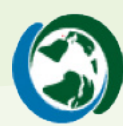

응응

으응

ज 3 을

옥

들.

ำ

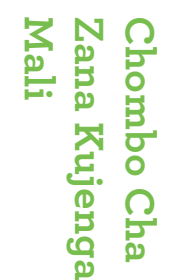

쪼고젇

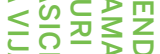

Z I

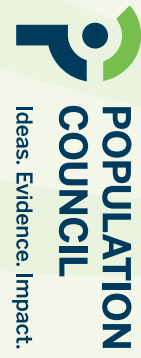

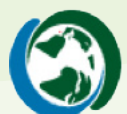

○ด

국응

ज 30

옥도

ด

ㅇํㅇ
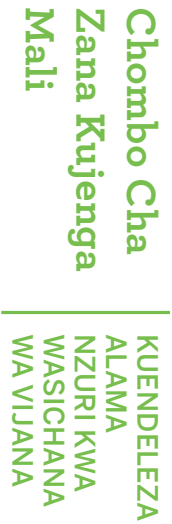
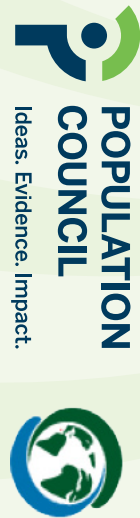

ำ

곡은

공

옥

ด

○ 

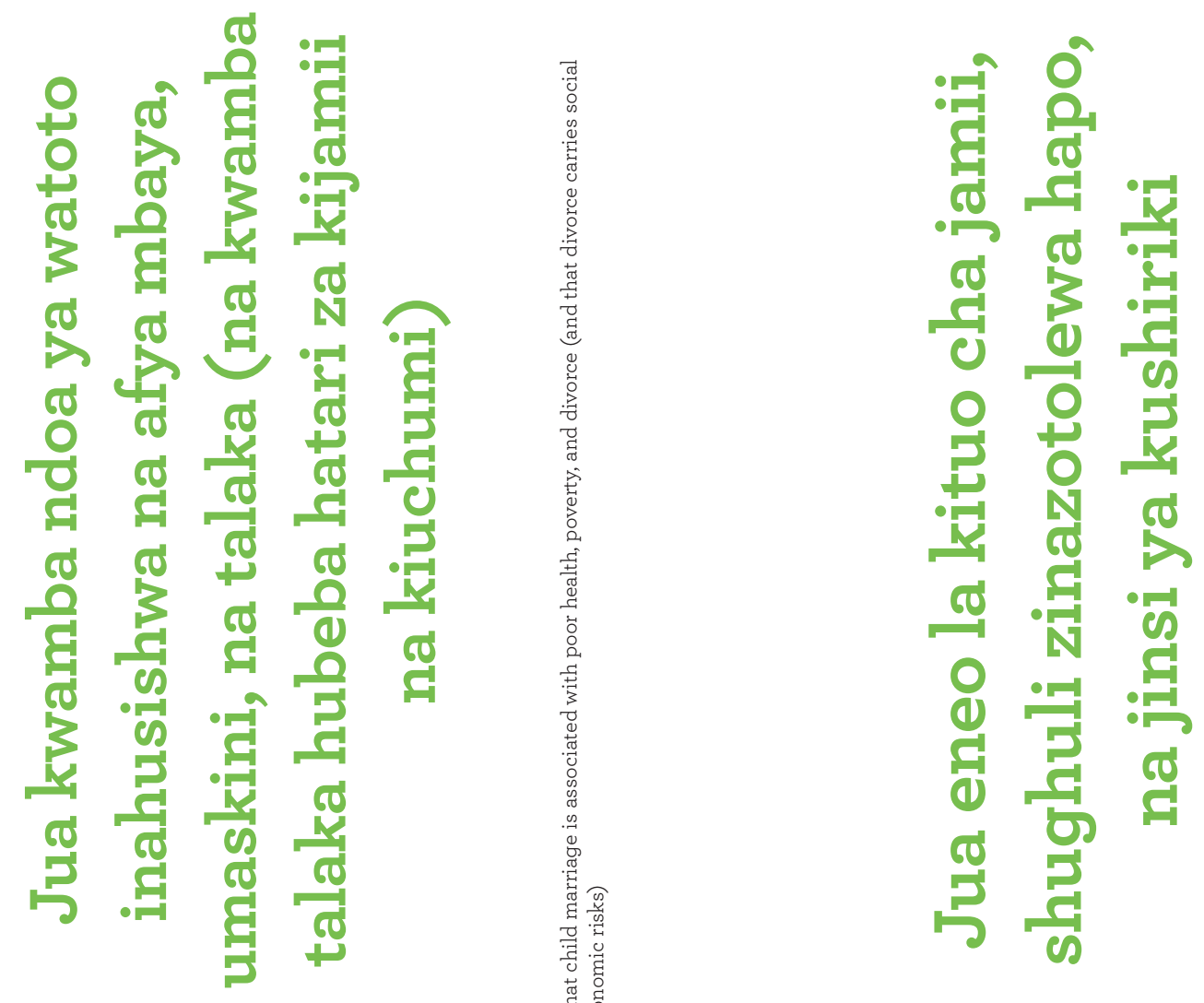

I
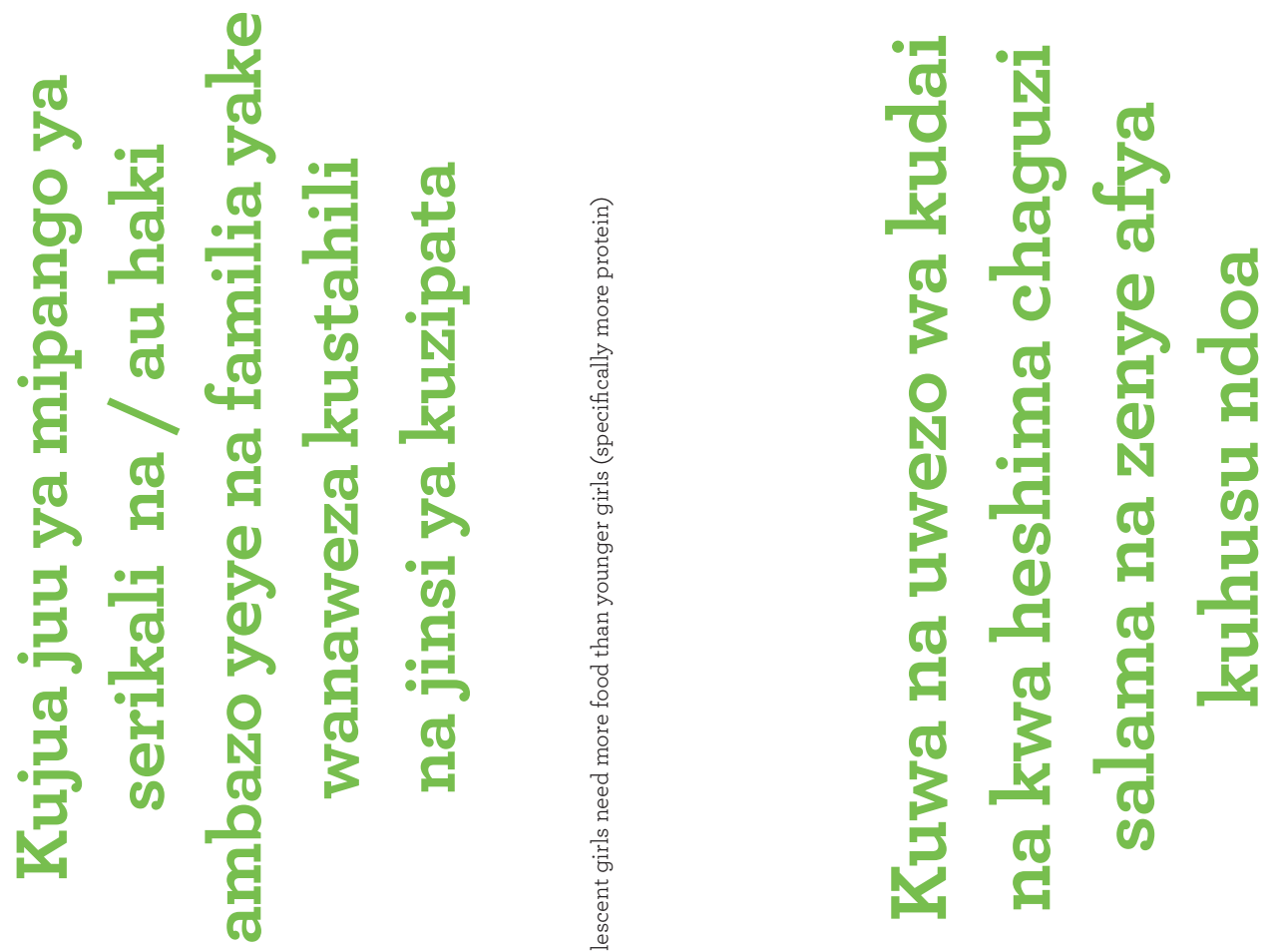


\section{0}

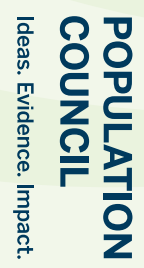

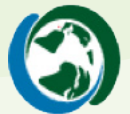

응응

(1)

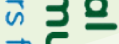

옥

คำ.

요
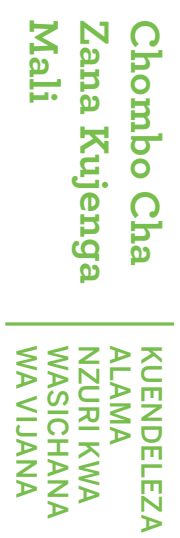

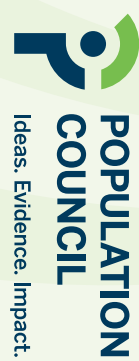

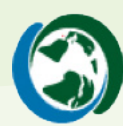

응응

으응

ज 3 을

옥

들.

ำ

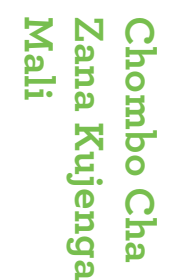

쪼고젇

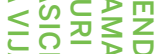

Z I

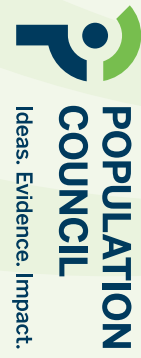

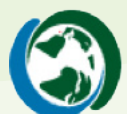

○ด

국응

ज 30

옥도

ด

ㅇํㅇ
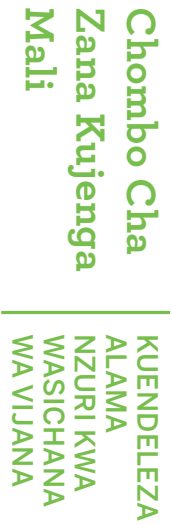
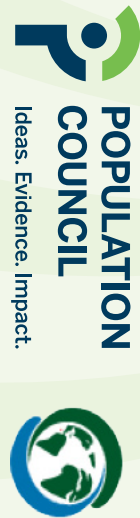

ำ

곡은

공

옥

ด

○ 

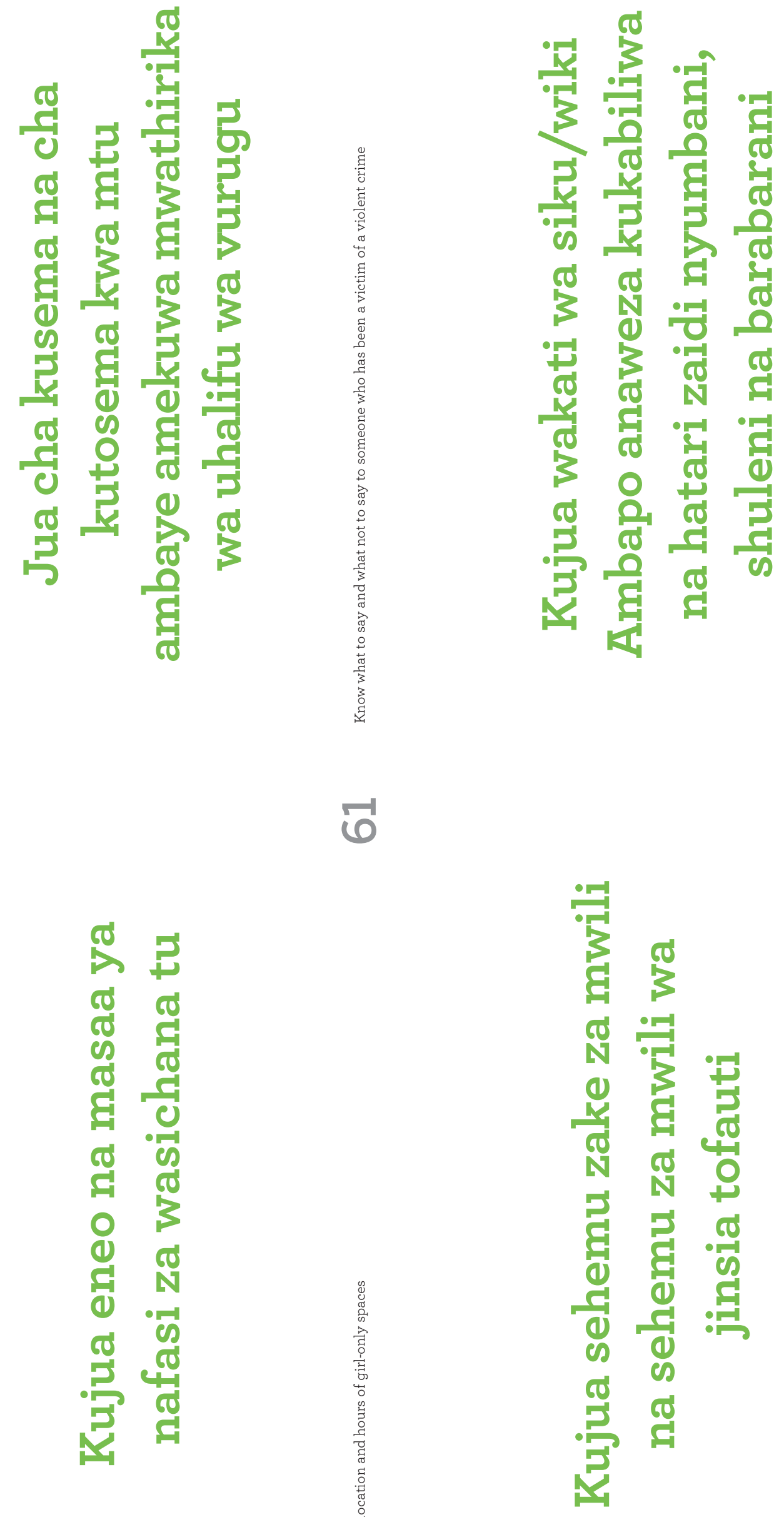


\section{0}

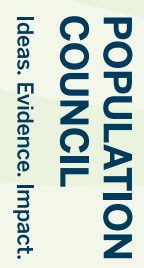

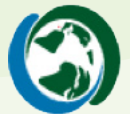

응응

(1)

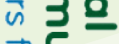

옥

คำ.

요
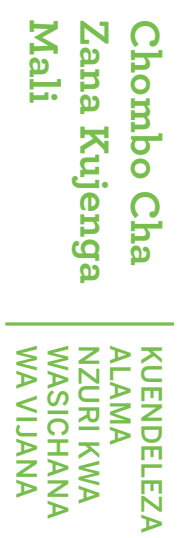

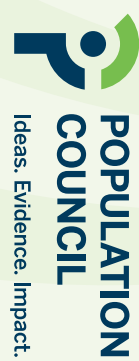

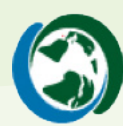

응응

으응

ज 3 을

옥

들.

ำ

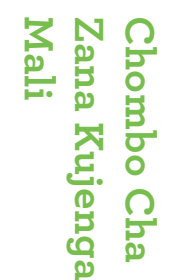

쪼고젇

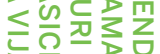

Z I

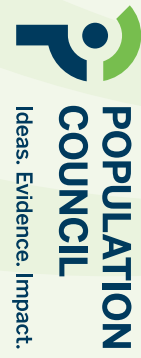

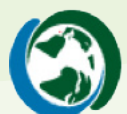

○ด

국응

ज 30

옥도

ด

ㅇํㅇ
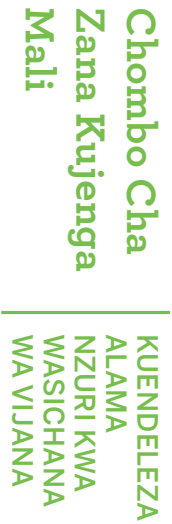
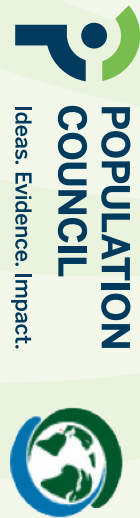

ำ

곡은

공

옥

ด

○ 

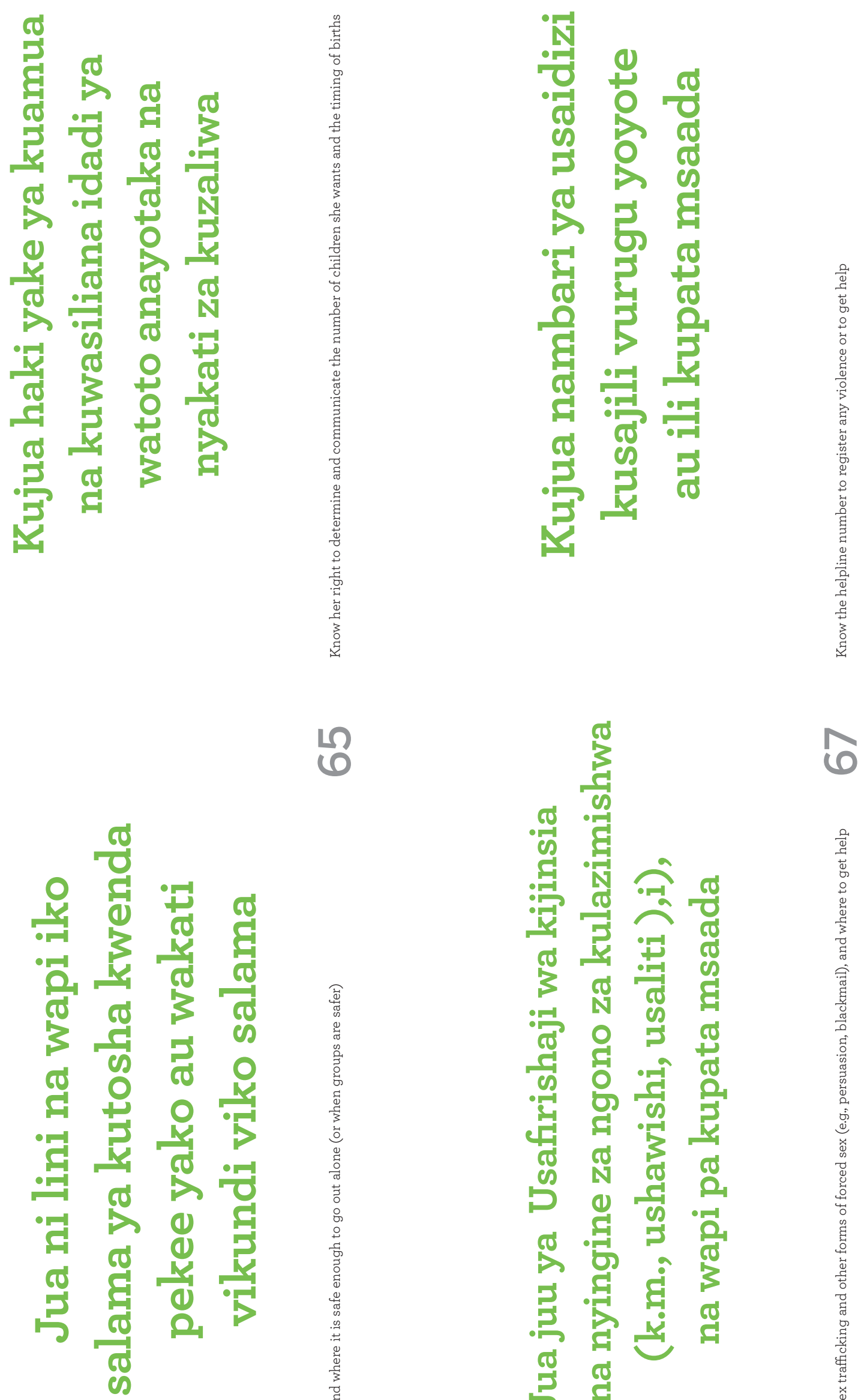

18
6
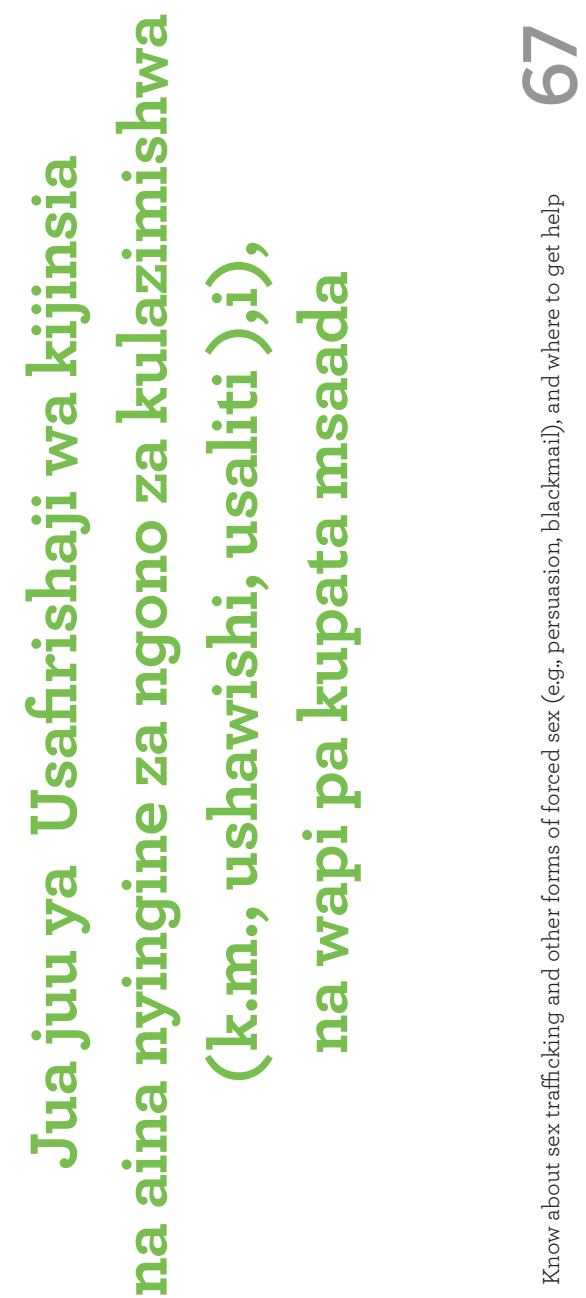


\section{0}

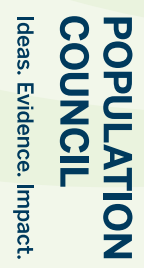

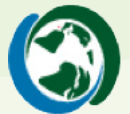

응응

(1)

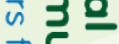

옥

คำ.

요
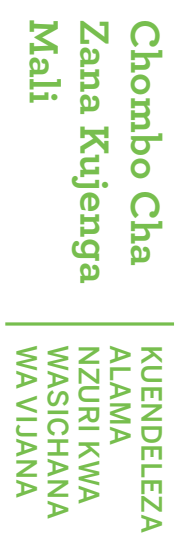

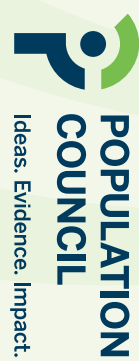

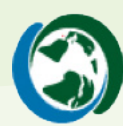

응응

으응

ज 3 을

옥

들.

ำ

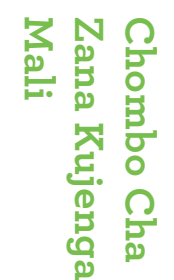

쪼고젇

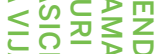

Z I

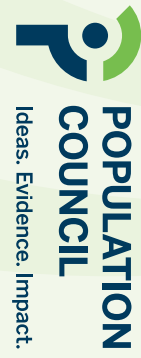

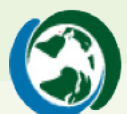

○ด

국응

ज 30

옥도

ด

ㅇํㅇ
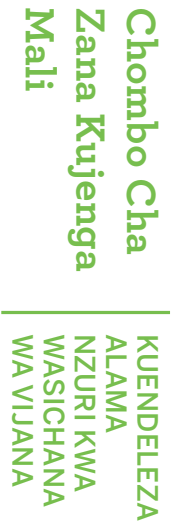
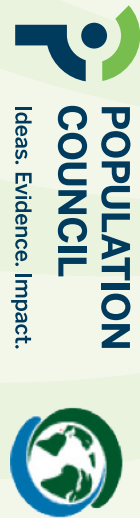

ำ

곡은

공

옥

ด

○ 

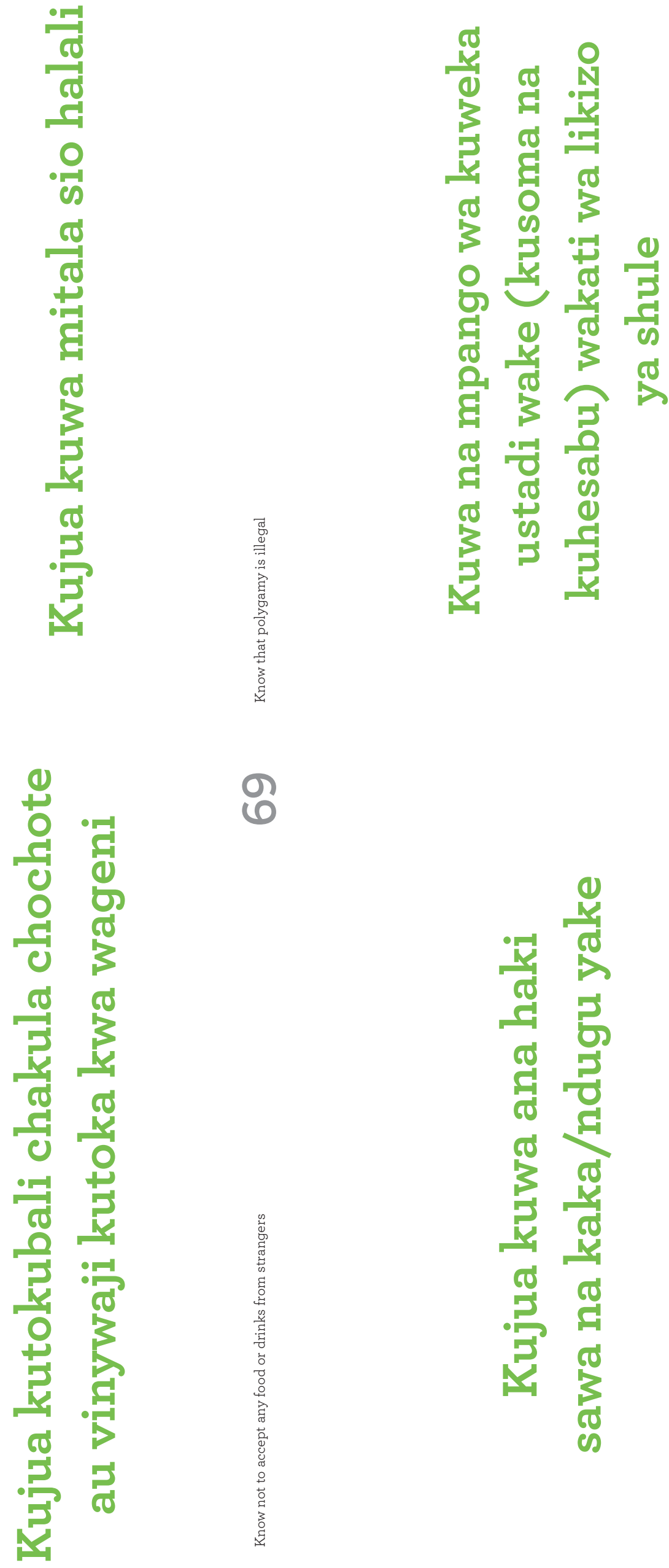

(0)
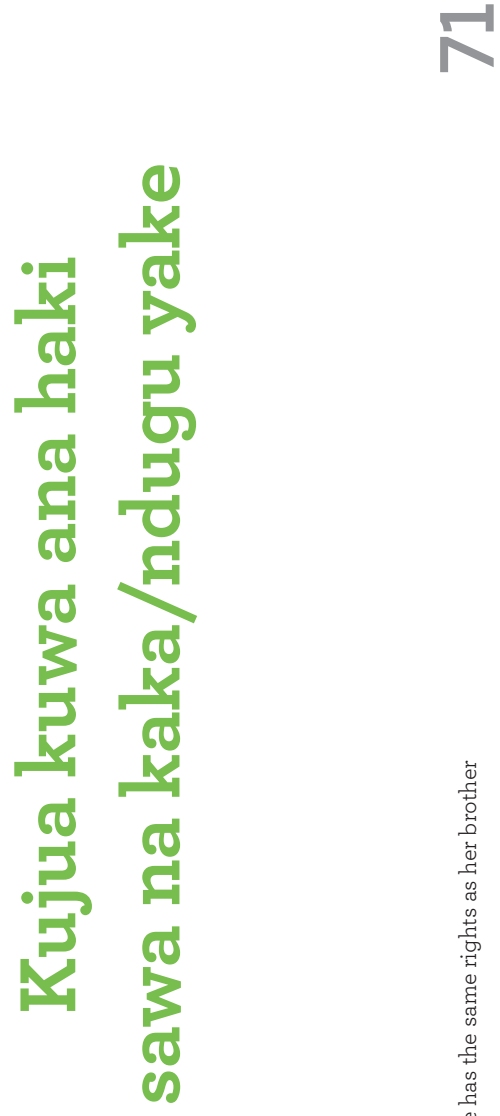


\section{0}

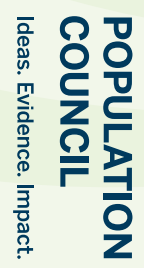

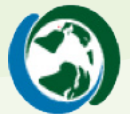

응응

(1)

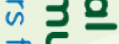

옥

คำ.

요
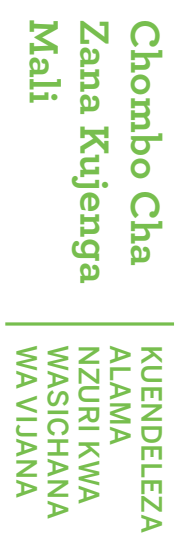

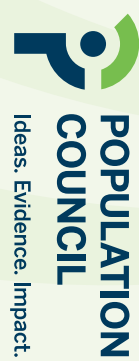

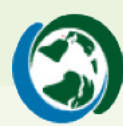

응응

으응

ज 3 을

옥

들.

ำ

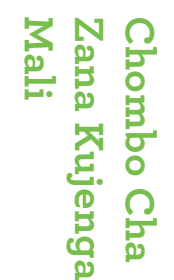

쪼고젇

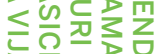

Z I

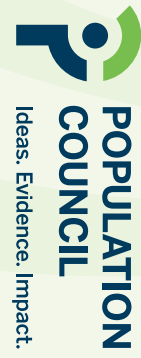

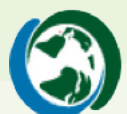

○ด

국응

ज 30

옥도

ด

ㅇํㅇ
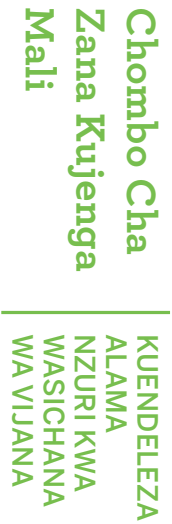
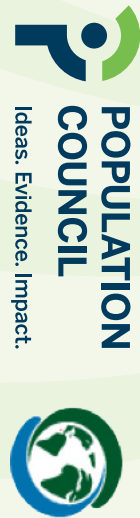

ำ

곡은

공

옥

ด

○ 

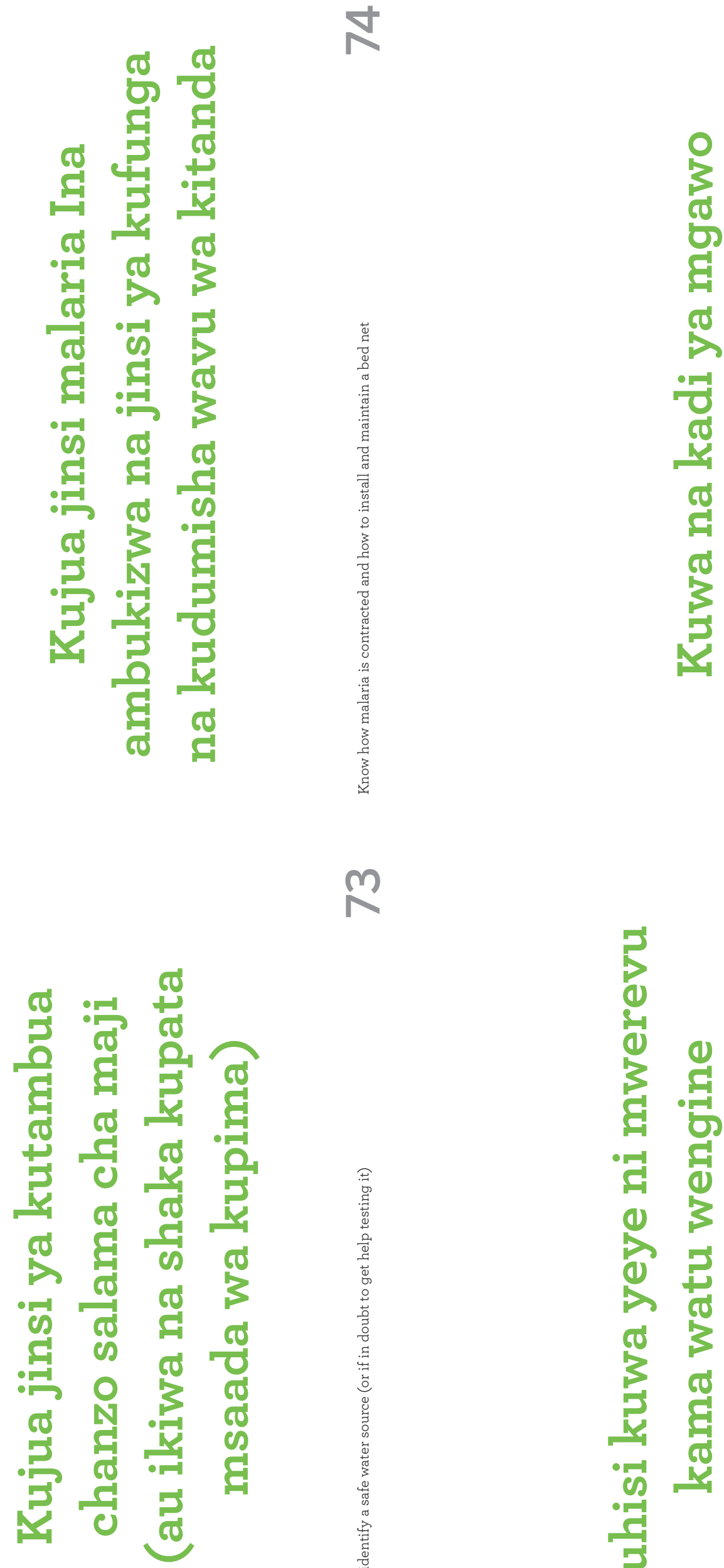

$m$
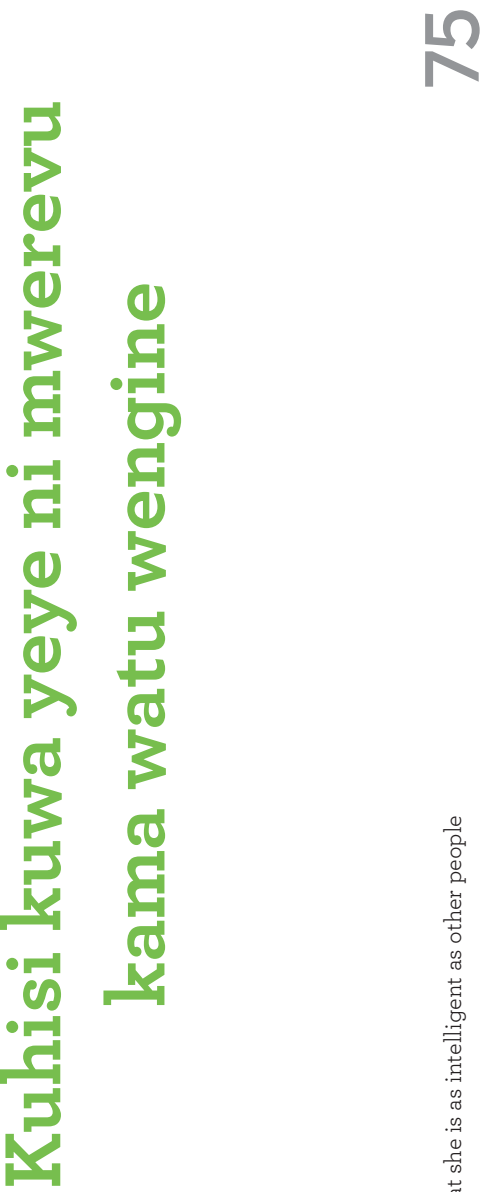


\section{0}

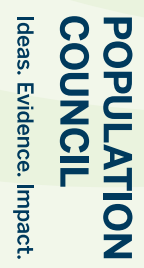

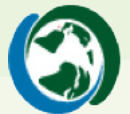

응응

(1)

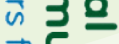

옥

คำ.

요
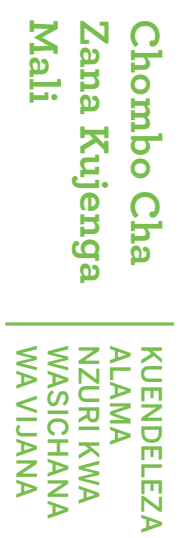

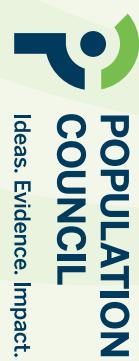

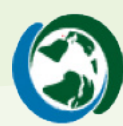

응응

으응

ज 3 을

옥

들.

ำ

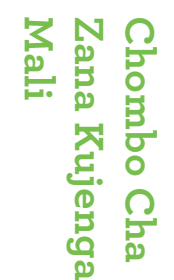

쪼고젇

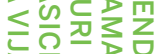

Z I

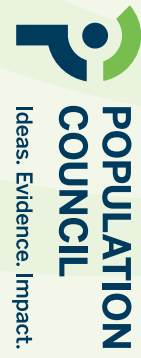

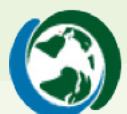

○ด

국응

ज 30

옥도

ด

ㅇํㅇ
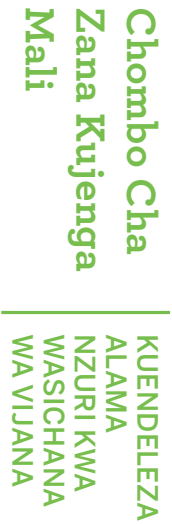
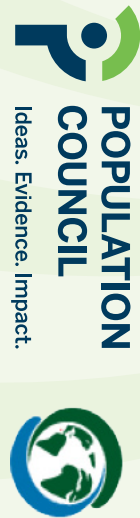

ำ

곡은

공

옥

ด

○ 

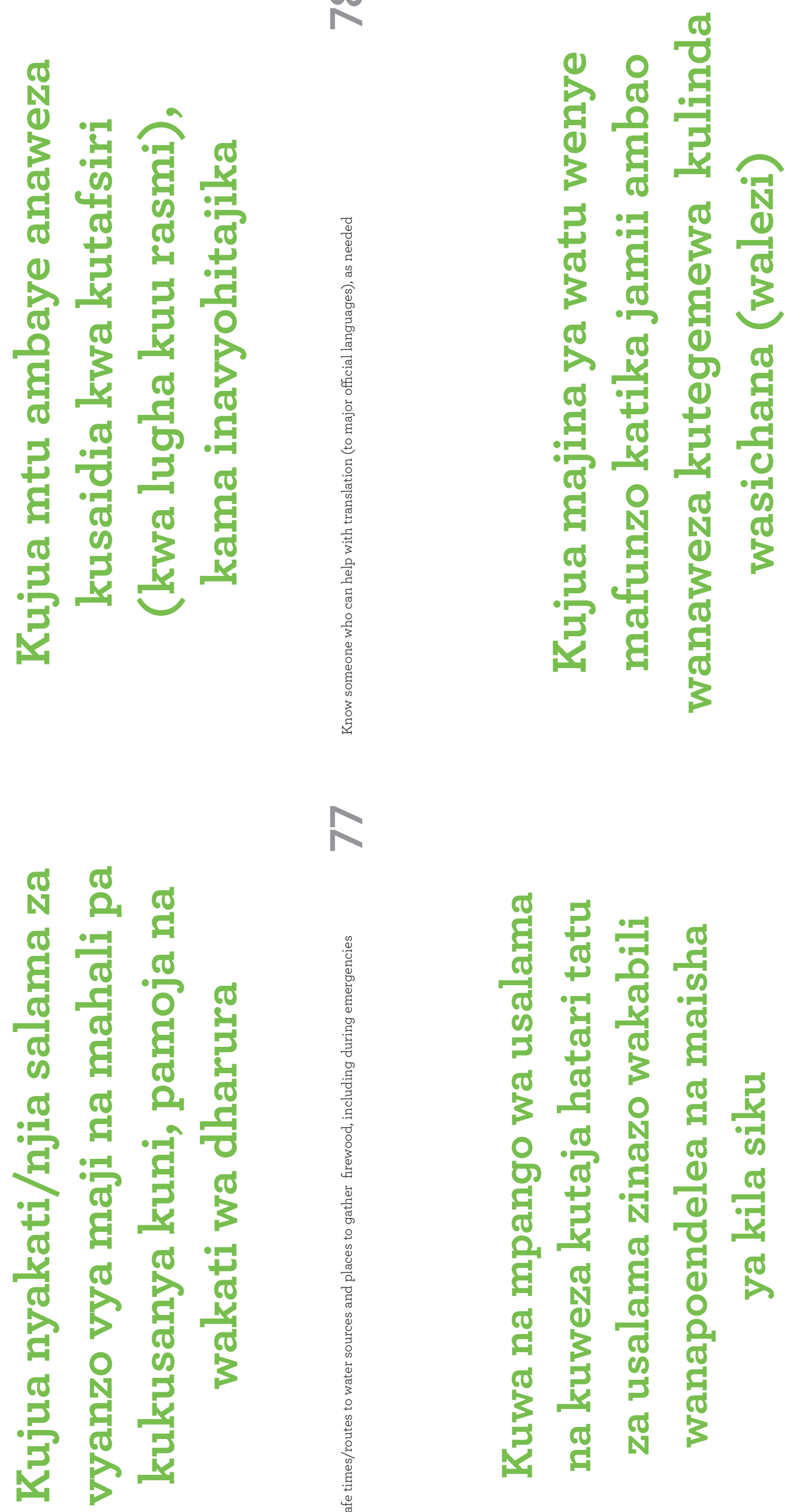


\section{0}

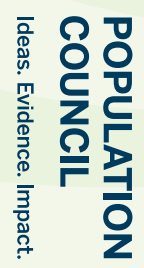

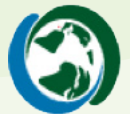

응응

(1)

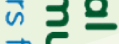

옥

คำ.

요
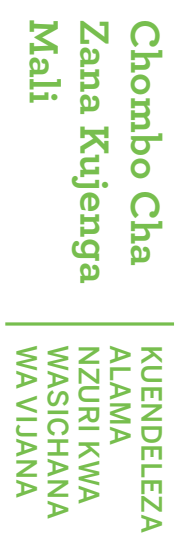

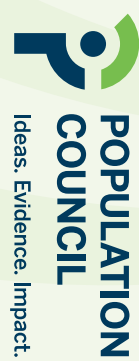

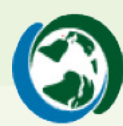

응응

으응

ज 3 을

옥

들.

ำ

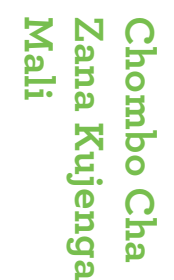

쪼고젇

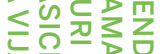

Z I

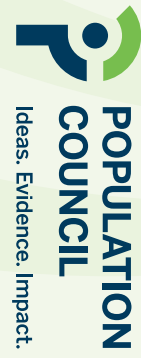

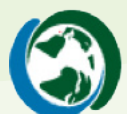

○ด

국응

ज 30

옥도

ด

ㅇํㅇ
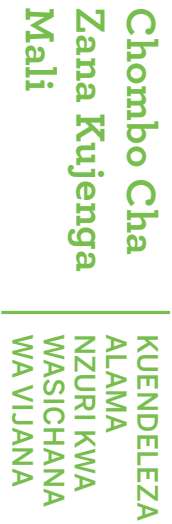
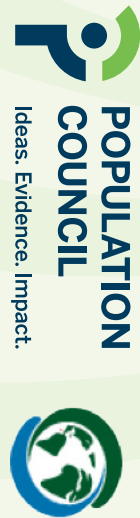

ำ

곡은

공

옥

ด

○ 

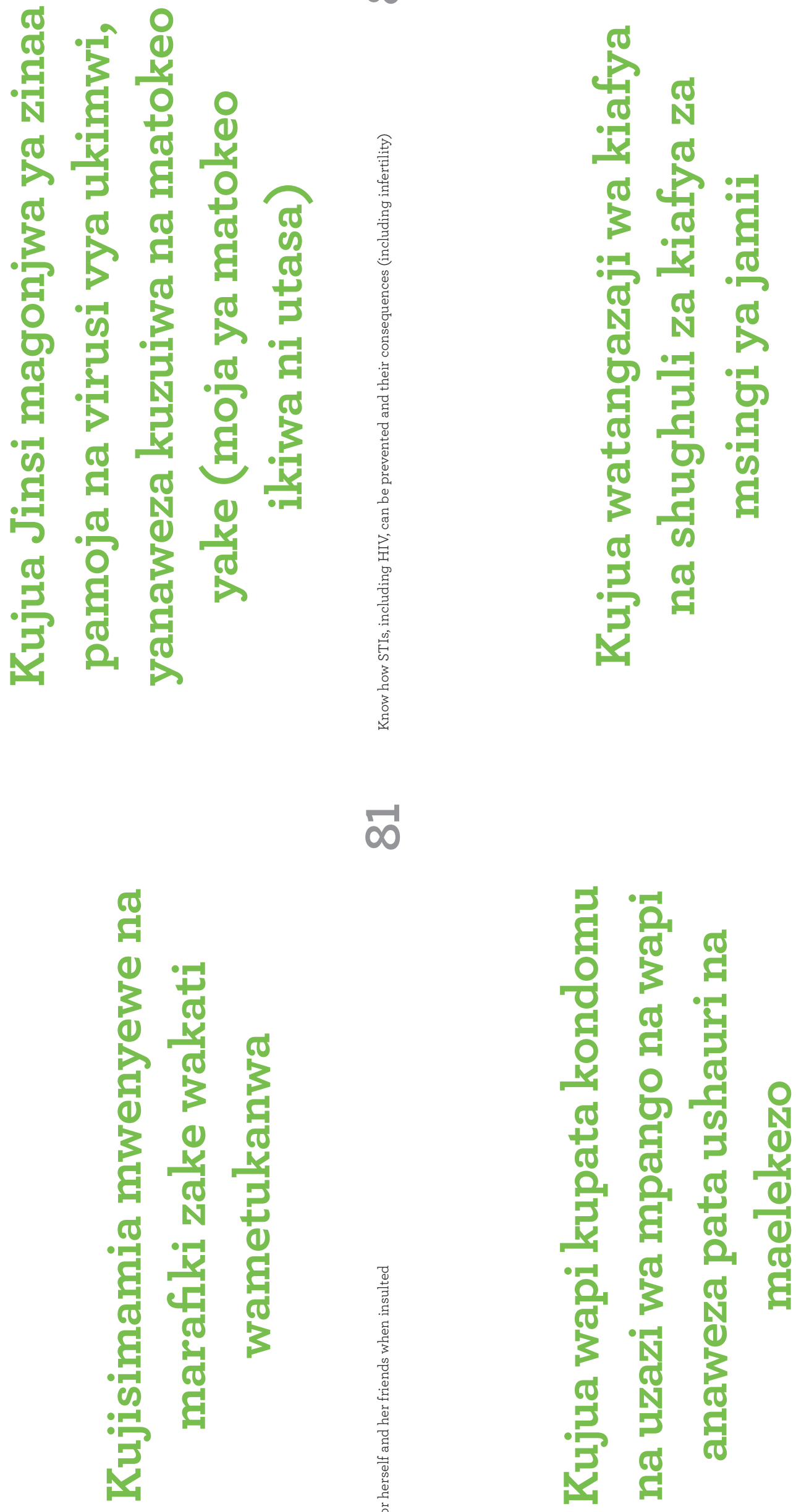


\section{0}

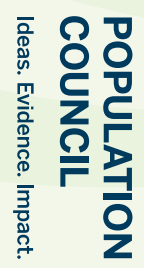

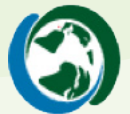

응응

(1)

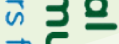

옥

คำ.

요
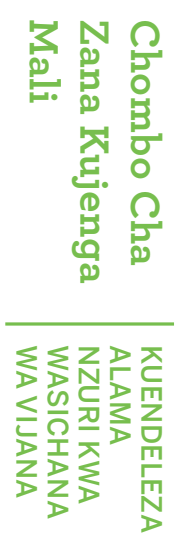

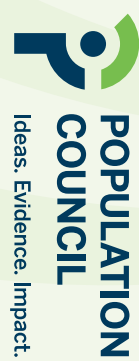

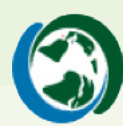

응응

으응

ज 3 을

옥

들.

ำ

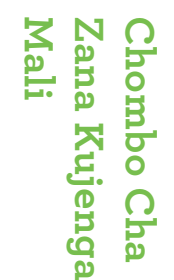

쪼고젇

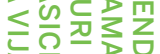

Z I

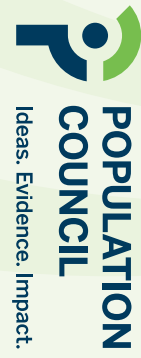

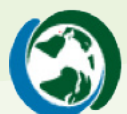

○ด

국응

ज 30

옥도

ด

ㅇํㅇ
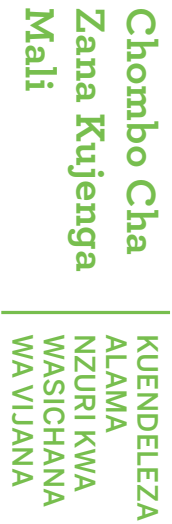
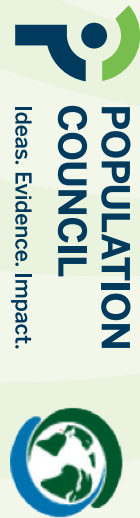

ำ

곡은

공

옥

ด

○ 


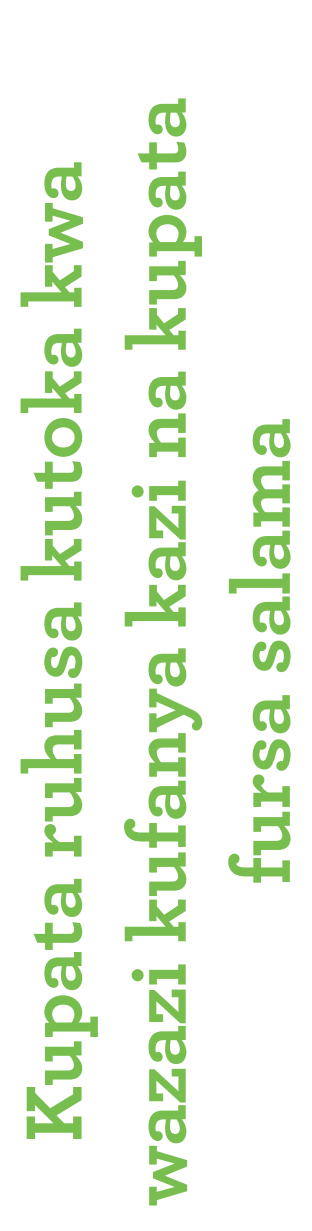

$\frac{6}{\infty}$
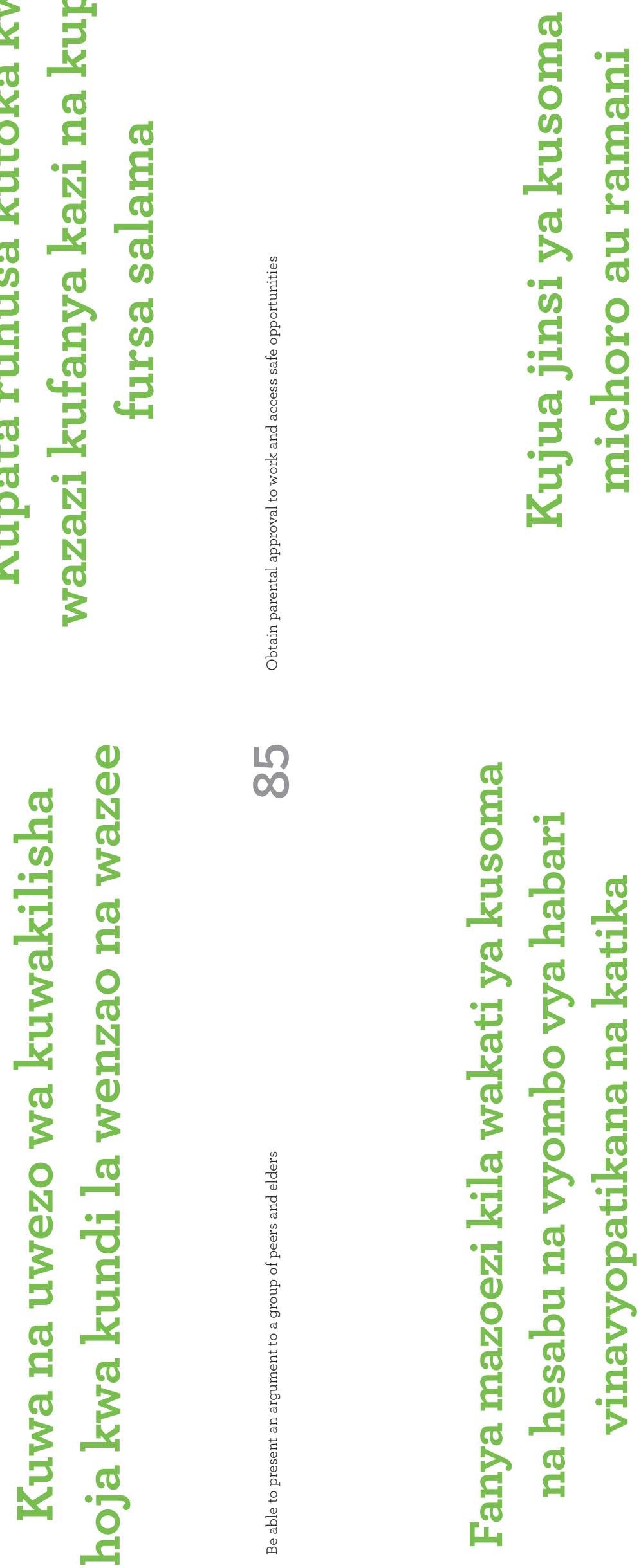

$1 \Omega$

$\infty$

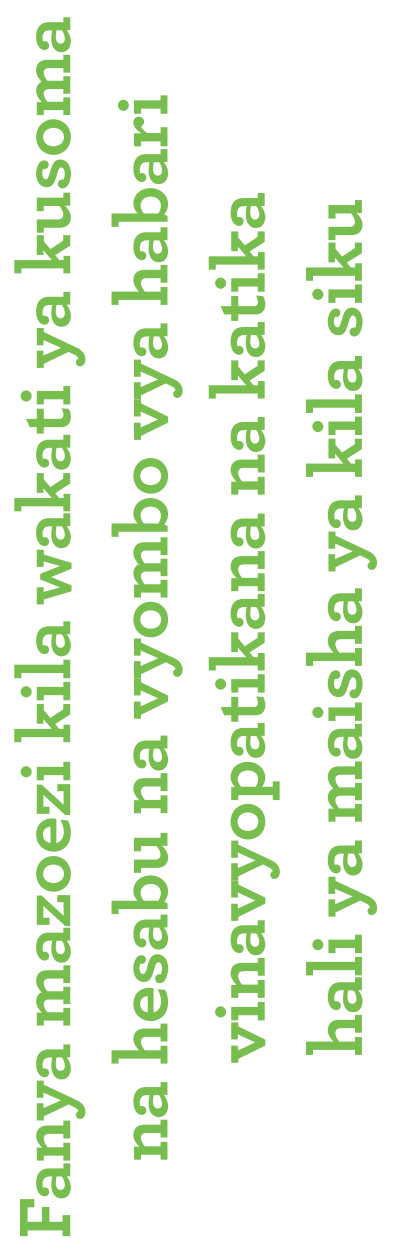




\section{0}

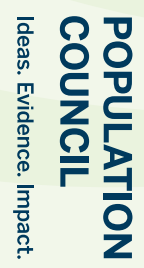

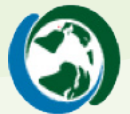

응응

(1)

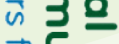

옥

คำ.

요
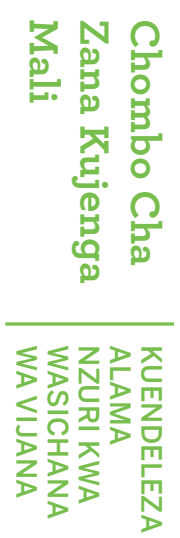

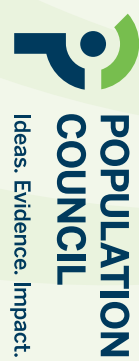

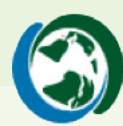

응응

으응

ज 3 을

옥

들.

ำ

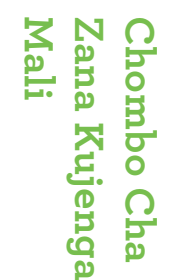

쪼고젇

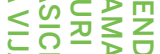

Z I

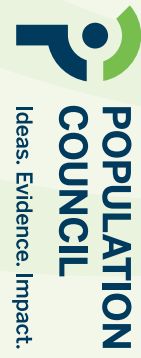

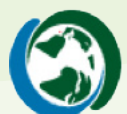

○ด

국응

ज 30

옥도

ด

ㅇํㅇ
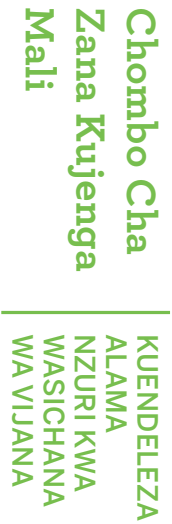
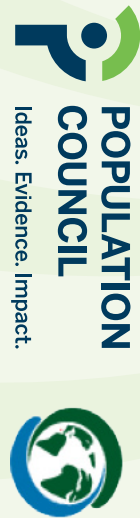

ำ

곡은

공

옥

ด

○ 

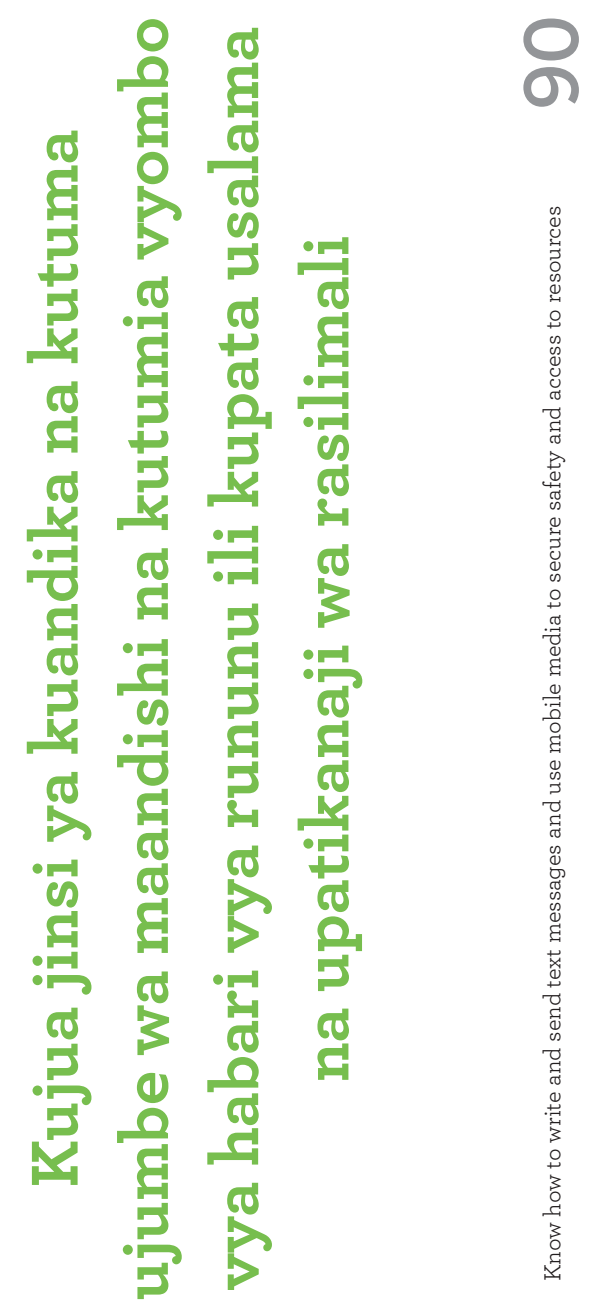

N

の
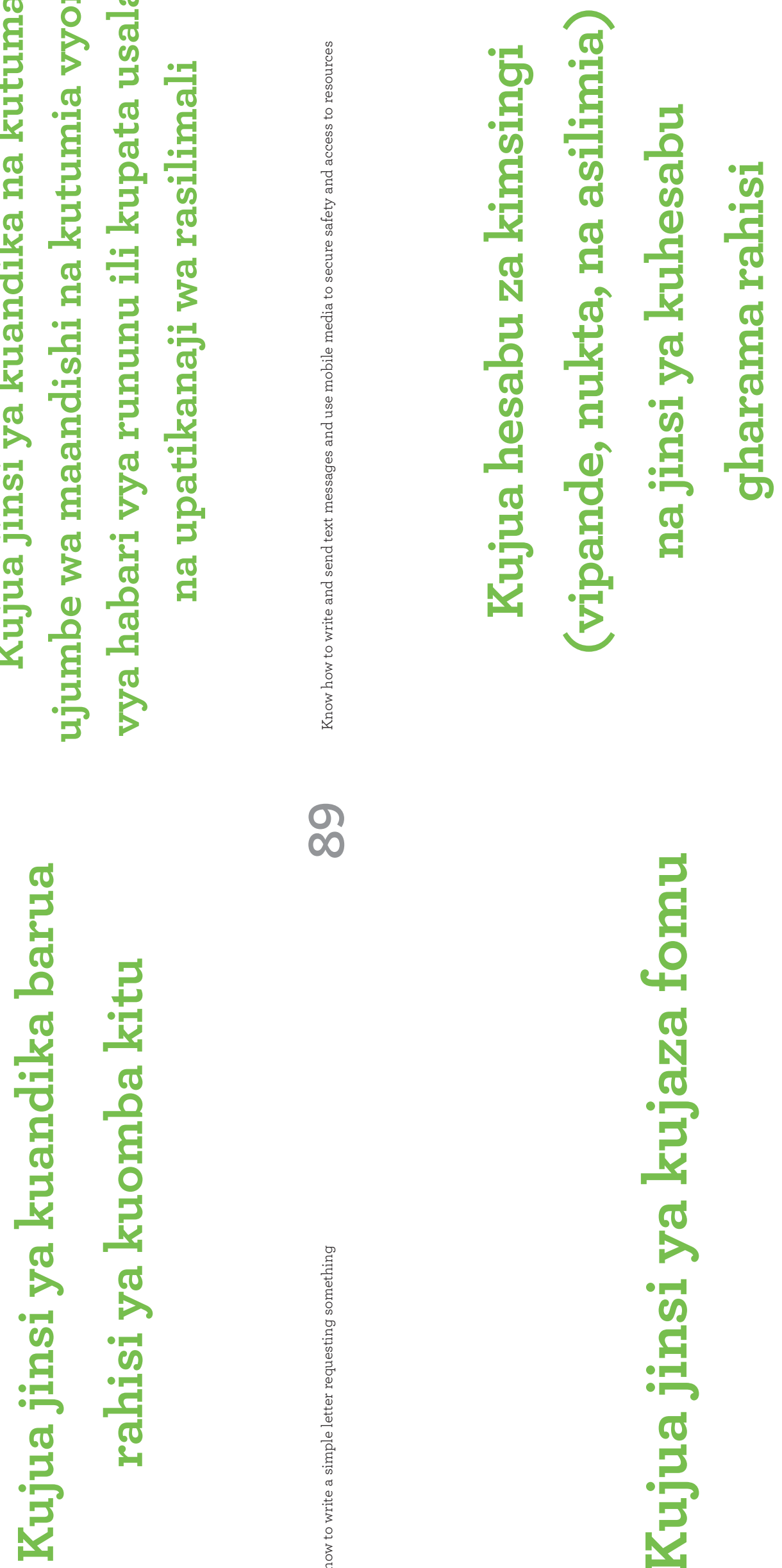

$\infty$

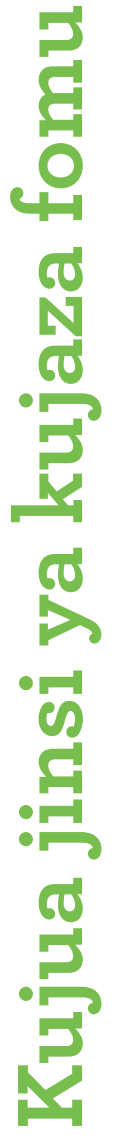




\section{0}

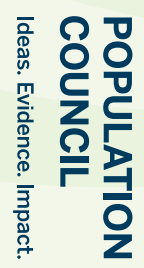

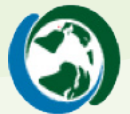

응응

(1)

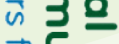

옥

คำ.

요
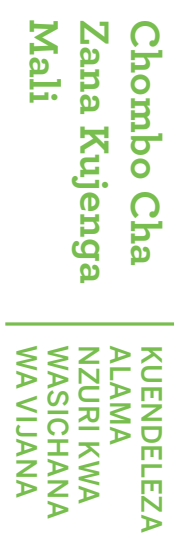

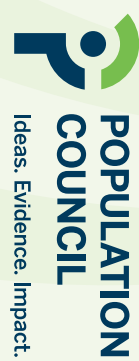

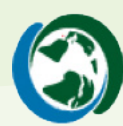

응응

으응

ज 3 을

옥

들.

ำ

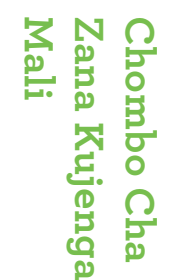

쪼고젇

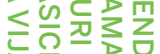

Z I

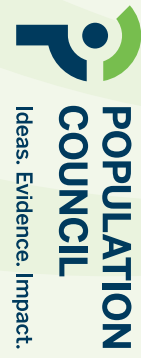

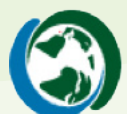

○ด

국응

ज 30

옥도

ด

ㅇํㅇ
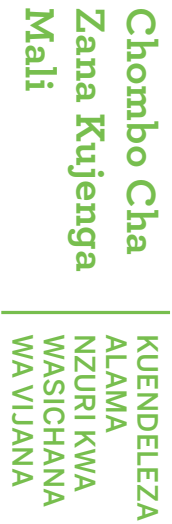
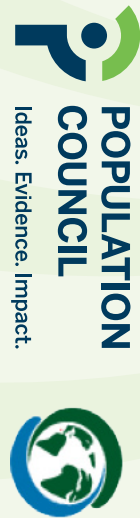

ำ

곡은

공

옥

ด

○ 

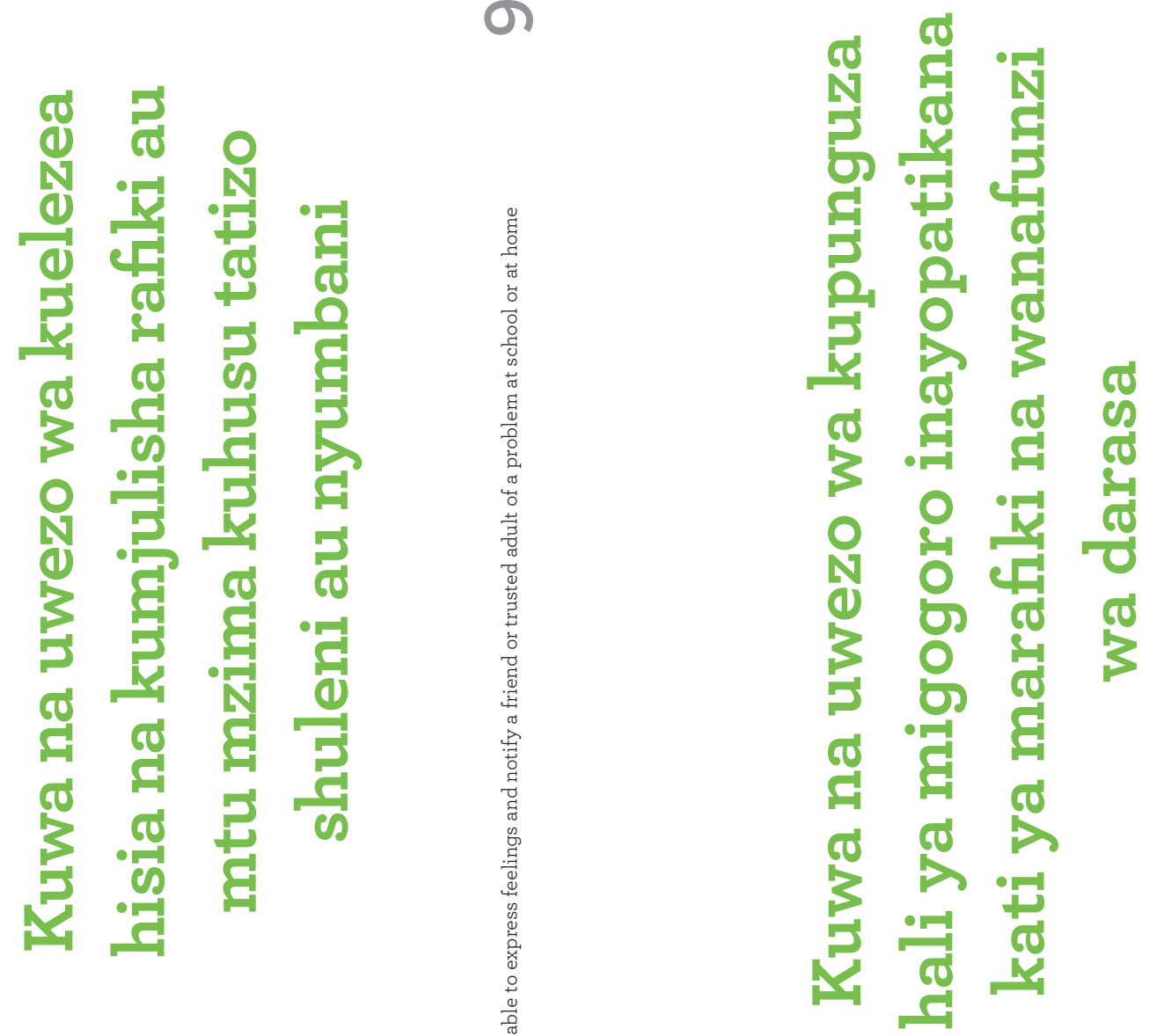

$m$
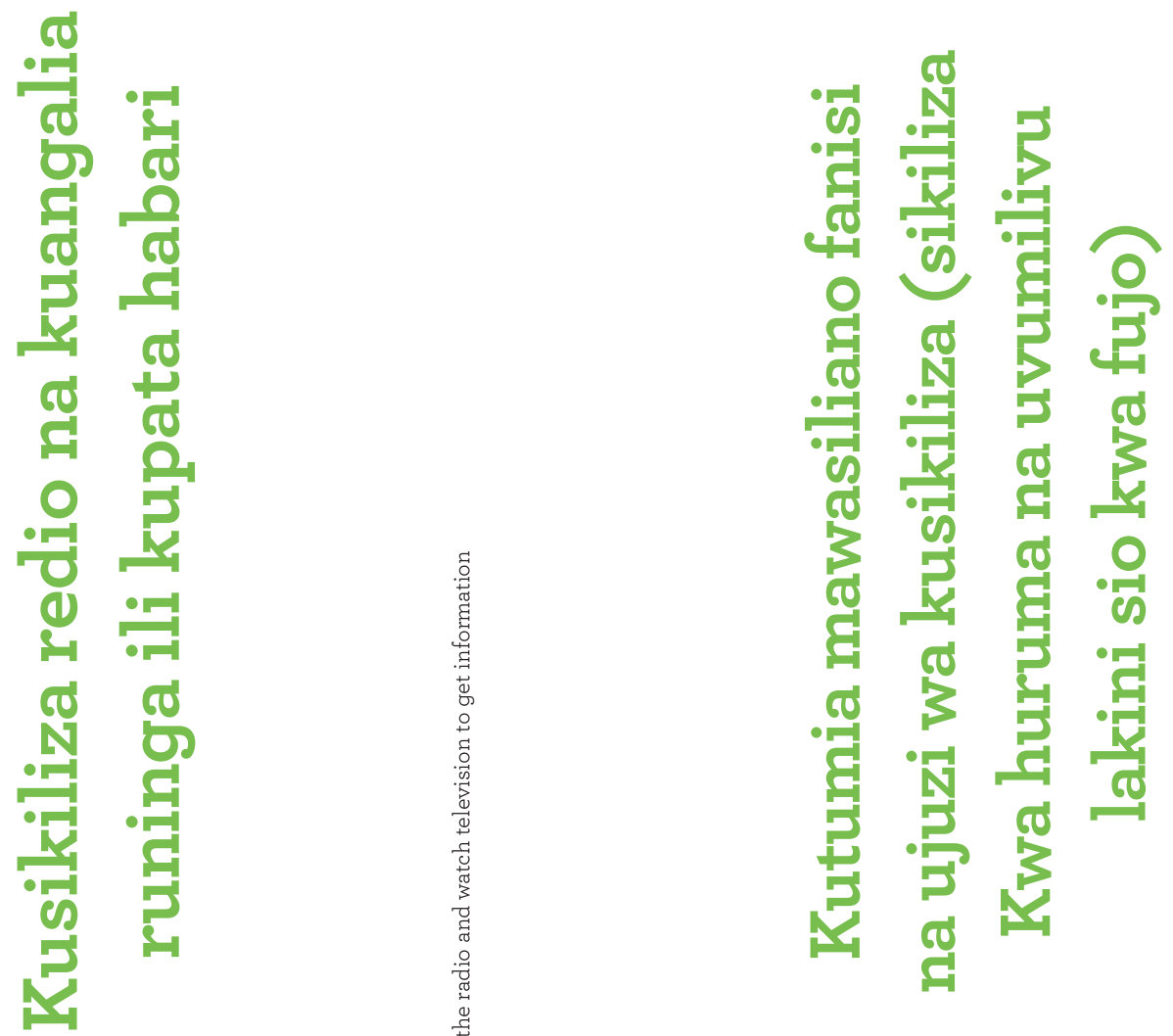


\section{0}

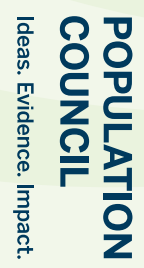

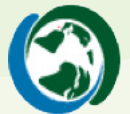

응응

(1)

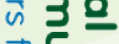

옥

คำ.

요
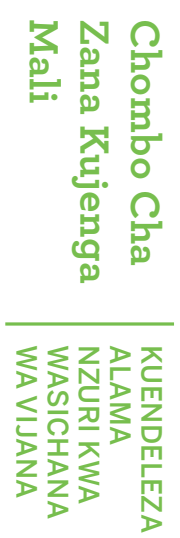

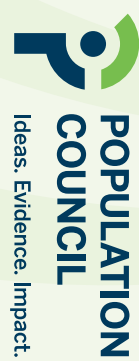

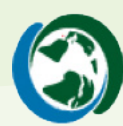

응응

으응

ज 3 을

옥

들.

ำ

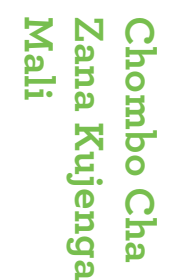

쪼고젇

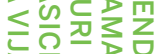

Z I

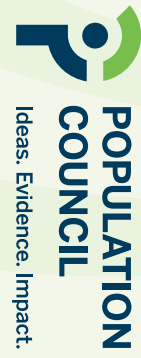

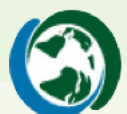

○ด

국응

ज 30

옥도

ด

ㅇํㅇ
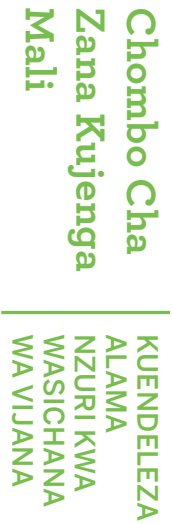
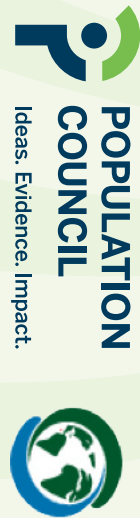

ำ

곡은

공

옥

ด

○ 

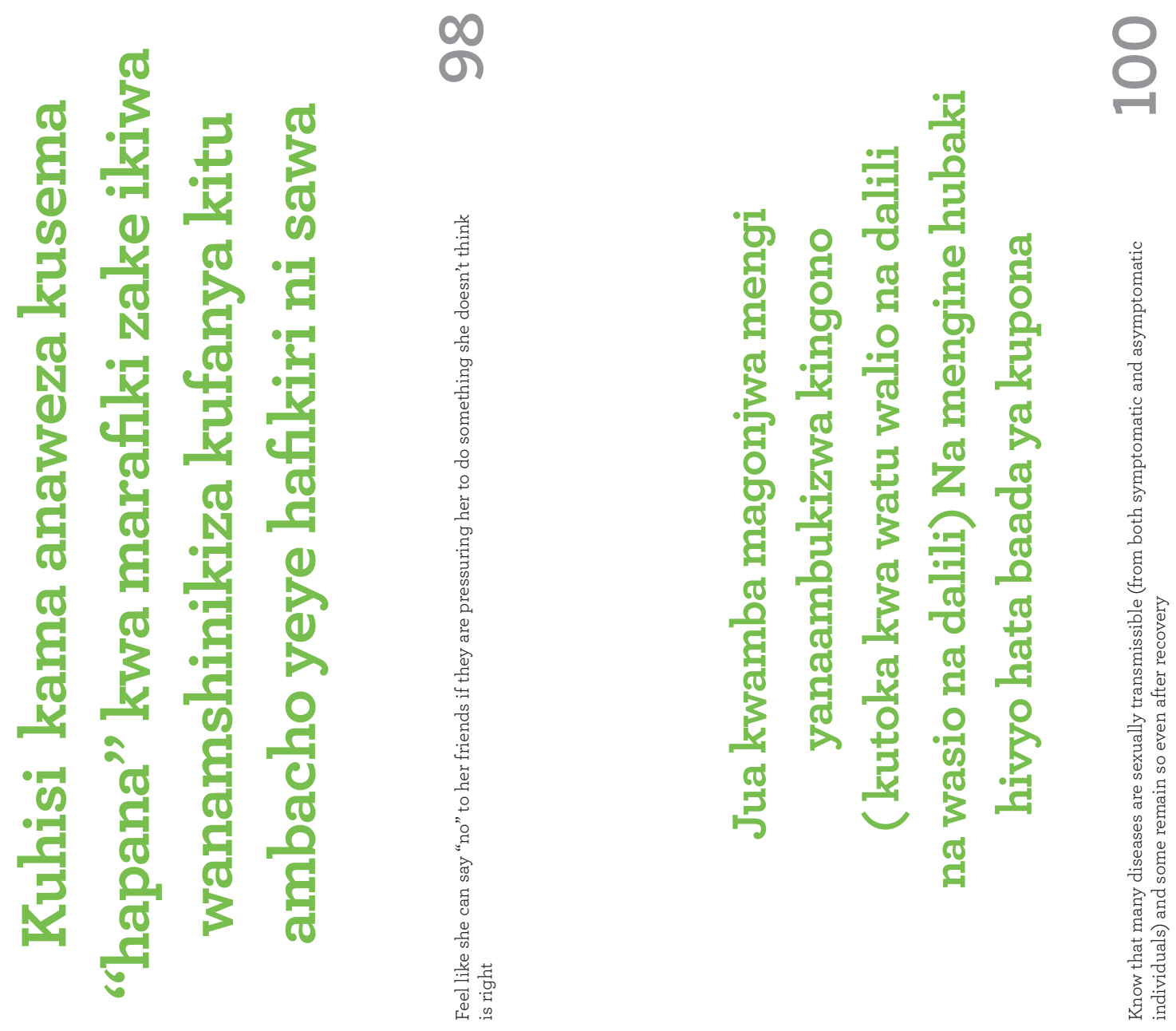


\section{0}

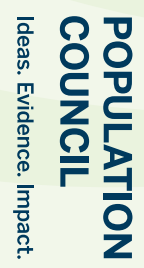

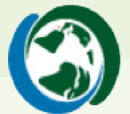

응응

(1)

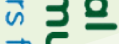

옥

คำ.

요
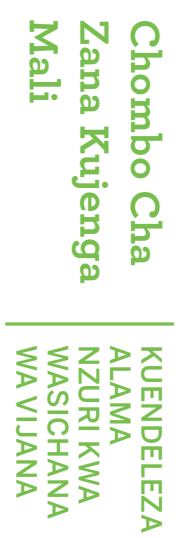

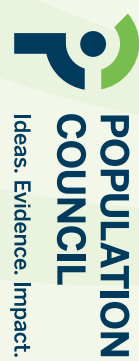

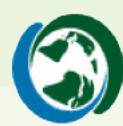

응응

으응

ज 3 을

옥

들.

ำ

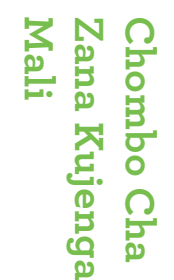

쪼고젇

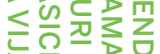

Z I

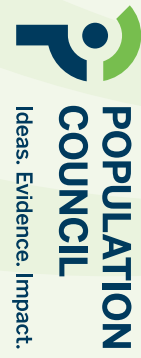

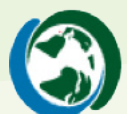

○ด

국응

ज 30

옥도

ด

ㅇํㅇ
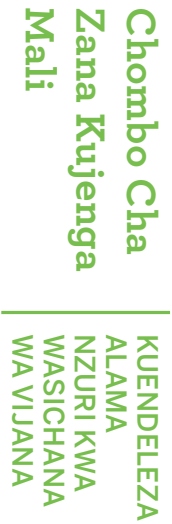
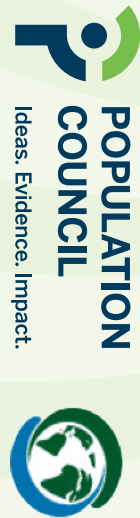

ำ

곡은

공

옥

ด

○ 


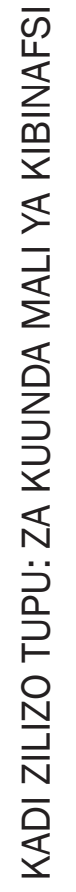





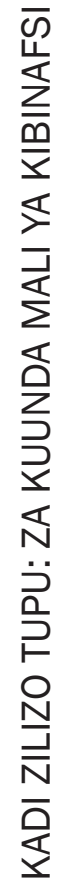





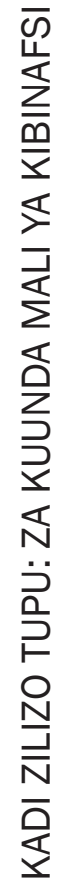



KADI ZA

MIAKA 


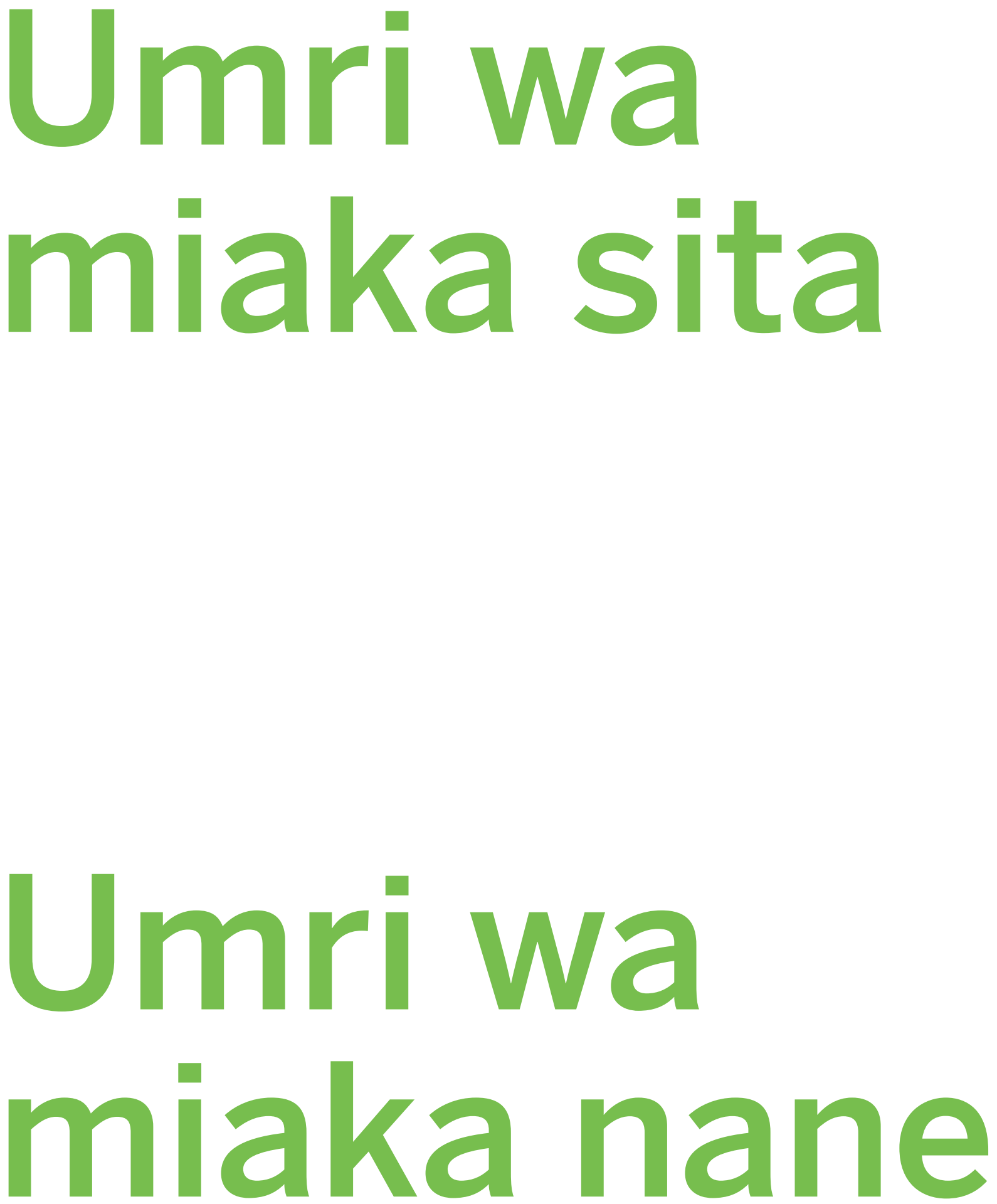


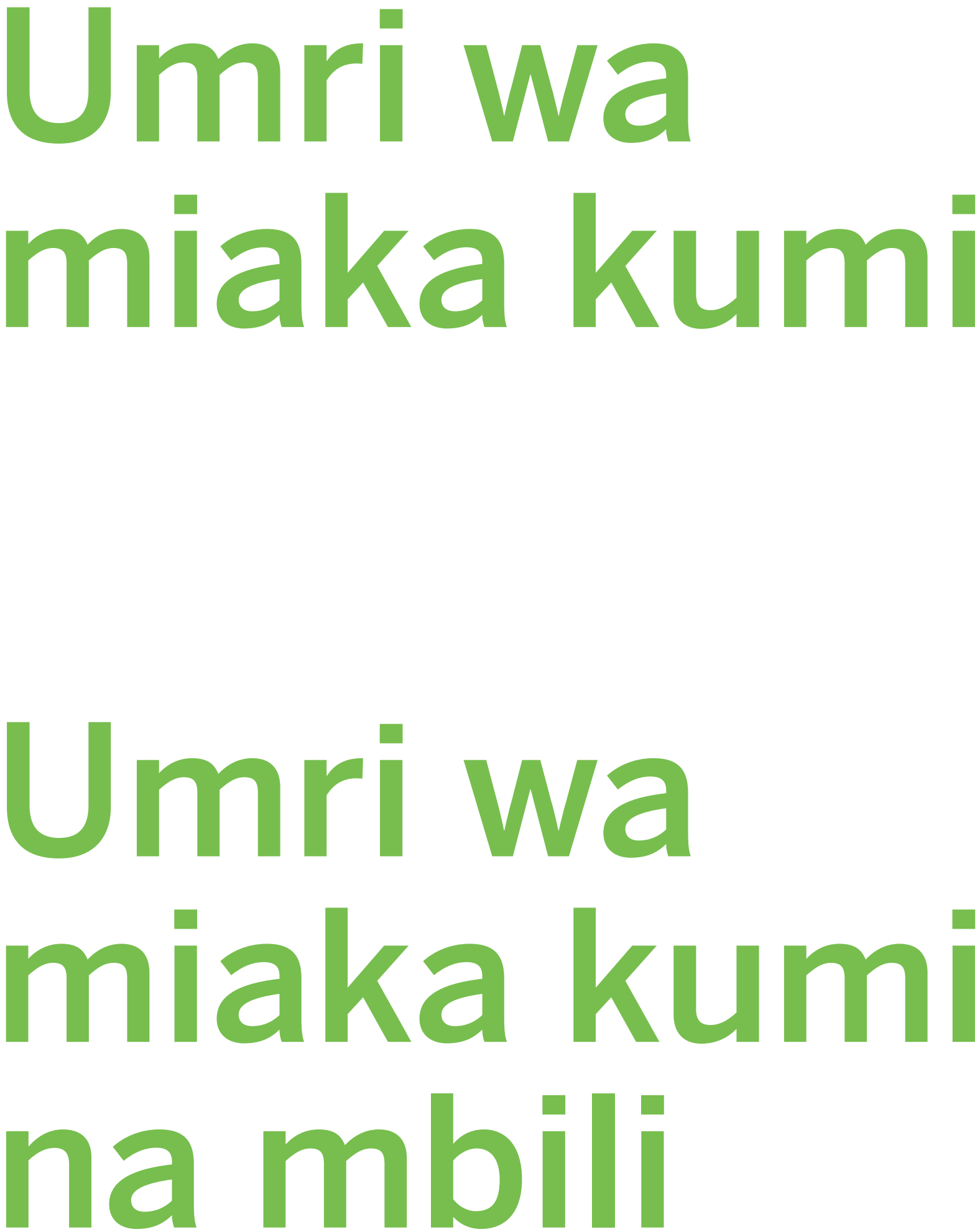

Umri wa
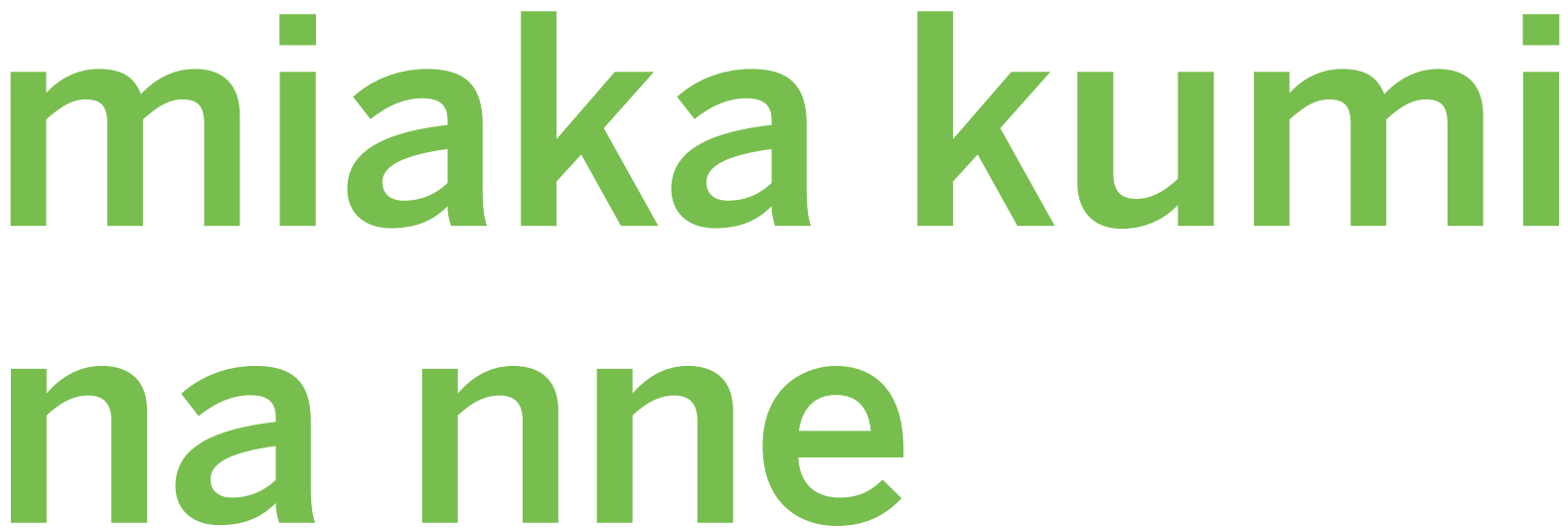

Umri wa

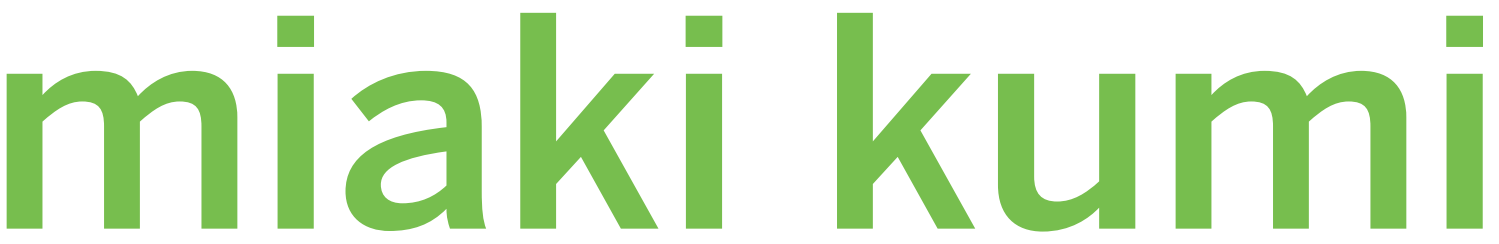

na sita 

Umri wa

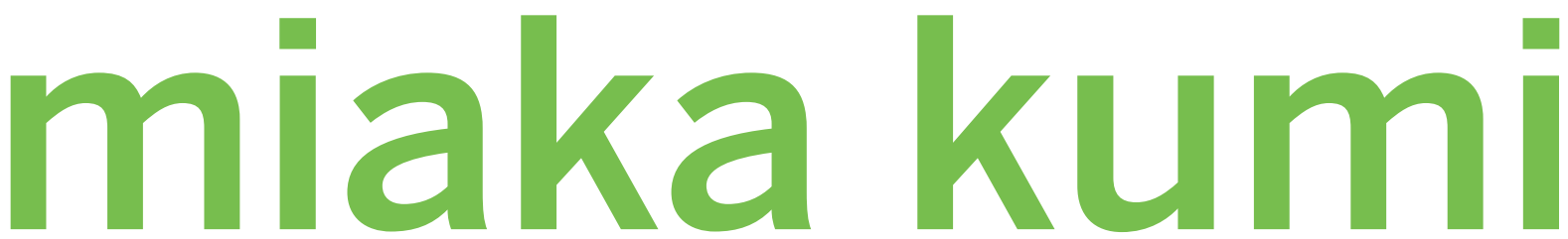

na hane
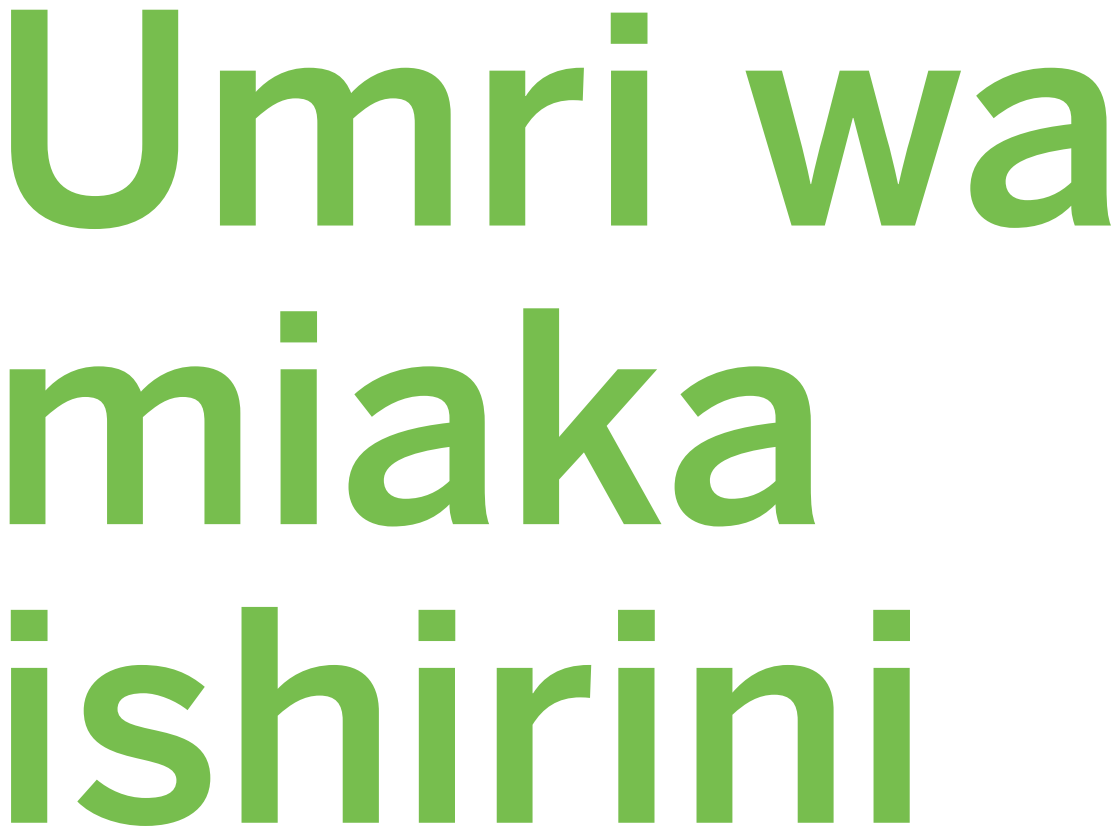